BULLETIN Bulletin hispanique

HISPANIQUE Université Michel de Montaigne Bordeaux

117-1 | 2015

Les poètes des rhéteurs

\title{
El Templo de la elocuencia castellana de Benito Carlos Quintero
}

Rafael Bonilla Cerezo

\section{(2) OpenEdition}

1 Journals

Edición electrónica

URL: https://journals.openedition.org/bulletinhispanique/3765

DOI: 10.4000/bulletinhispanique.3765

ISSN: 1775-3821

Editor

Presses universitaires de Bordeaux

Edición impresa

Fecha de publicación: 1 junio 2015

Paginación: 95-142

ISBN: 979-10-300-0174-7

ISSN: 0007-4640

Referencia electrónica

Rafael Bonilla Cerezo, «El Templo de la elocuencia castellana de Benito Carlos Quintero», Bulletin hispanique [En línea], 117-1 | 2015, Publicado el 01 junio 2018, consultado el 11 febrero 2022. URL:

http://journals.openedition.org/bulletinhispanique/3765 ; DOl: https://doi.org/10.4000/

bulletinhispanique.3765

Tous droits réservés 


\title{
El Templo de la elocuencia castellana de Benito Carlos Quintero
}

\author{
Rafael Bonilla Cerezo \\ Universidad de Córdoba
}

Le "Temple de l'éloquence castillane " (1629) du docteur Benito Carlos Quintero (resté mystérieux encore aujourd'hui) s'édifie sur deux discours, le dernier à l'usage des prédicateurs. Les deux discours composent l'une de ces rhétoriques dont les chercheurs, non sans quelque légèreté, n'ont pas vu l'intérêt. La présente étude analyse chacun des arguments de l'opuscule, très suggestif, de l'auteur salmantin. Il en éclaire les sources pour le situer - ne serait-ce que comme mince filet d'eau - dans cette inondation de lettres, d' "antidotes ", de pareceres ou d'avis, déclenchée par la diffusion des Solitudes de Góngora (1613-1614) et la prédication de Paravicino (1615-1633).

Mots-clés : rhétorique du baroque, rhétorique et prédication, Quintero, Góngora, Paravicino, Ormaza, Céspedes, polémique gongorine.

El Templo de la elocuencia castellana (1629) del aún hoy misterioso doctor Benito Carlos Quintero, se levanta sobre dos discursos -el segundo de los cuales enderezó al uso de los predicadores- que sostienen una de las retóricas que los estudiosos han despachado con cierta ligereza. Analizo en este trabajo cada uno de los argumentos del sugestivo opúsculo del salmantino, iluminando sus fuentes y anclándolo, siquiera como arroyuelo, a la caudalosa riada de cartas, antídotos y pareceres suscitados por la difusión de las Soledades de Góngora (1613-1614) y la predicación de Paravicino (1615-1633).

Palabras clave: retórica del Barroco, retórica y predicación, Quintero, Góngora, Paravicino, Ormaza, Céspedes, polémica gongorina.

The "Templo de la elocuencia castellana» (1629), written by the still mysterious Dr. Benito Carlos Quintero, is built on two discourses - the second one devoted to the use of preachers. Both constitute a rhetoric book that scholars have cast aside with some thoughtlessness. This paper analyses in each the arguments of the highly suggestive book of this priest of Salamanca, lighting sources and anchoring it, even as a stream, to the mighty flood of letters, 'antidotes' and 'views' raised by the diffusion of Góngora’s Soledades (1613-1614) and Paravicino’s (1615-1633) preaching.

Keywords: Baroque Rhetoric, Rhetoric and Preaching, Quintero, Góngora, Paravicino, Ormaza, Céspedes, Controversy about the Góngora’s Texts. 
G 1 Templo de la elocuencia castellana (1629) del aún hoy misterioso Benito E Carlos Quintero, natural de Salamanca, según reza en la portada de la edición sevillana de este libro, se levanta sobre dos discursos -el segundo de los cuales enderezó al uso de los predicadores- que sostienen una de las retóricas que los estudiosos han despachado con cierta ligereza. Solo Martí (1972: 291297) y García Berrio (1980: 214-218, 397-399 y 460-463) le dedicaron unos capítulos hace ya casi cuatro décadas, mientras que el resto apenas si lo citan - caso de hacerlo- entre los preceptistas del Barroco.

Al margen de su secular olvido, procuro anclarlo aquí, siquiera como arroyuelo, a la caudalosa riada de cartas, antídotos y pareceres suscitados por la difusión de las Soledades ${ }^{1}$. Porque las tesis de este doctor castellano, por lo que atañe al ars bene dicendi -y también al scribendi-, discurren más que paralelas a la querelle acerca de los poemas mayores (1612-1614) de Góngora; y diría que importan, asimismo, para rastrear una etapa muy concreta de nuestra oratoria sacra: aquella (1615-1633) que deriva del magisterio de Hortensio Paravicino, «caracterizada por un registro culto que ocasionó terribles resistencias y luchas literarias» (Cerdan 1994a: 14 y 1994b: 22-23)².

Lo primero que sorprende del Templo de Quintero es que circulara el mismo año por dos sedes distintas. Citaré la editio princeps cuyo frontispicio remite a la oficina hispalense de Luis Estupińán, y que además incorpora: la aprobación de Juan de Robles, responsable del Culto sevillano (1631), retórica dialogada en la que repitió más de un argumento del tratado que nos ocupa ${ }^{3}$; la licencia

1. Sobre esta vasta controversia véanse Jammes (1994: 605-719), Roses Lozano (1994), Osuna Cabezas (2009) y Roses (2007: 81-119). Un equipo de investigadores -entre los que me cuentodirigido por Mercedes Blanco (Université Paris-Sorbonne) afronta en la actualidad la edición de cada uno de esos documentos: «Para una edición digital de la polémica gongorina» (CLEA 3-OBVIL): (http://www.paris-sorbonne.fr/la-recherche/les-ecoles-doctorales/ed-3/labex-obvil/).

2. Véase también Herrero Salgado (2006: 66-158). A propósito del cercano parentesco entre la oratoria sagrada y la poesía en el mundo hispánico del siglo XVII, Blanco (2012: 33 y 35) sostiene que "Góngora y Paravicino anduvieron unidos, para bien y para mal, a ojos de los hombres de su tiempo, y no solo porque eran amigos. Ni siquiera solo porque formaban parte de algo que habría que llamar, con términos anacrónicos, una clique o coterie, enfrentada con otras: en el frente de la poesía, con la de Lope de Vega; en el frente de la oratoria sagrada, con otros predicadores del rey, como el jerónimo Gabriel Pedrosa o el jesuita amigo de Lope, el padre Florencia. [...] Pero aún más que por esta singularidad del estilo, [...] los hombres de su tiempo admiraron o aborrecieron a Paravicino, como a Góngora, por haber sabido buscar y encontrar algo ignoto hasta entonces, [...] una nueva concepción del sermón, como de la poesía, de sus fines y de sus posibles virtudes estéticas y retóricas».

3. Rico Verdú (1973: 191) fue pionero en percatarse de la huella del Templo sobre el arte del onubense, al que volveré más tarde. Gómez Camacho (1992: 14) amplía que el Culto, en 1629, «se encuentra ya muy avanzado. Sin embargo hay diferencias muy notables entre esta versión y la obra para la que se solicitan licencias de impresión en 1631. No se menciona el quinto diálogo, que trata de la ortografía, y se promete un prólogo que no aparece en el manuscrito colombino; comenta que ya no citará tanto a Bartolomé Jiménez Patón porque ha encontrado la retórica de Espinosa, cuando el Culto es en realidad un resumen casi literal de las obras de Baltasar de Céspedes desde el principio [su fuente principal, junto con las de Herrera y Horacio]; por último, [...] aparecen [citados textos] que se imprimieron en 1629 [el Templo de la elocuencia, p. 72] y 1630». El inciso entre corchetes es mío. 
de Luis Venegas de Figueroa, gobernador, provisor y vicario general de Sevilla; la dedicatoria del autor al «ilustre y noble caballero Alejandro Grimaldo»; un soneto laudatorio («Tú, del sacro Tormes dulce hijo»), salido de la pluma de Juan de Zabaleta; y dos décimas («Tantos los aciertos son» y "Clicie, al sol enamorada»), en el haber de Jerónimo de Abarca y Juan Infante de Olivera (u Olivares). El cotejo que ha realizado Giulia Giorgi entre este volumen y el que indica en la portada «Salamanca, por los talleres de Rodrigo Calvo» no ha arrojado diferencias, excepción hecha del frontis y del cuaderno con los paratextos legales y las composiciones epidícticas ${ }^{4}$. Por ello tiendo a pensar en una tirada única.

Difícil averiguar la causa que movió a Quintero a elegir a la vez, como canales de distribución, la ciudad del Tormes y la capital andaluza, en cuyo círculo de intelectuales parece que halló buen acomodo y mejor patrocinio. La mayor parte de los problemas derivan de la oscura biografía de nuestro rétor, pues se ignora todo acerca de su trayectoria, en el supuesto de que viniera al mundo -como se presume- en las últimas décadas del siglo $\mathrm{XVI}^{5}$. Incluso convendría dejar en cuarentena el hecho de que solo escribiera el Templo de la elocuencia castellana, aun cuando haya quien opine (Martí 1972: 291; Galbarro 2010: 84) que la paternidad de tan curiosa obrita recayó más bien sobre su hermano Jacinto, sacerdote y firmante de dos libros homiléticos aparecidos poco después ${ }^{6}$. Con todo, se antoja natural que el Templo se le venga atribuyendo a Benito, ya que alude en dos pasajes a los sermones de Jacinto. Verbigracia en la dedicatoria

4. Giulia Giorgi (Università di Ferrara) ultima la edición del Templo de la elocuencia castellana. Es curioso que García Berrio (1980: 214), al desconocer esta doble transmisión, anotara que «la portada escrita a pluma, por la falta de la original, en el ejemplar de la Biblioteca Nacional de Madrid que manejo (sign. 2-64787) da como fecha y lugar de la edición, Salamanca, 1629, con letra más moderna, tachando la indicación manuscrita original que daba por lugar Sevilla y la misma fecha». Anécdota nimia que confirma la circulación de la edición hispalense -en mayor o menor grado- por la España barroca.

5. Disponemos, eso sí, de un dato significativo, facilitado por el propio autor en el Templo: su actividad como poeta de academia, o al menos como asistente y polemista en varios cenáculos: "compitiendo en una Academia de Madrid si la poesía castellana vencía en artificio a la latina, trayendo muchos versos en su amparo, cierto de gala y primor, yo me acuerdo que referí los de Horacio, libro I, oda 1, donde con el ruido de las voces significa la carrera de los coches olímpicos, la velocidad de las ruedas y el tropel de los caballos tan vivo en su corteza como en el alma de la significación» (Quintero 1629: 33v).

6. Discursos evangélicos de Cuaresma, Madrid, 1651, in 4º; Sermones de santos o Panegíricos sagrados, Madrid, 1652, in 4º. Quintero dejó inconcluso al morir su Commentarium in Jonam Prophetam, que luego terminaría Pedro de Quirós. Por desgracia, tanto en los Discursos como en los Sermones el teólogo omitió su segundo nombre de pila («Carlos»). Véanse Vidal y Díaz (2007: 551), Nicolás Antonio (1783: I, 613) y Menéndez Pelayo (1887). Pascual Barea (2009: 623638), que atribuye el Templo de la elocuencia castellana a Jacinto, editó su Epistola Commendatitia (fols. 4r-5r), hallada en el códice manuscrito autógrafo de la obra de Rodrigo Caro Veterum Hispaniae deorum manes sive reliquiae. Señala asimismo que «la segunda colección [de sermones], impresa a costa del mercader libros Juan de San Vicente con numeración conjunta para todo el volumen, está dedicada a Juan Jiménez de Góngora, ministro en la corte de Felipe IV, y contiene sermones predicados en Sevilla, además de Madrid, Alcalá de Henares o Toledo» (Pascual Barea 2009: 629-630). 
al genovés Grimaldo, recibidor de este par de discursos por «la amistad que tiene usted con el Padre Jacinto Quintero de los Clérigos Reglares Menores, mi hermano y mi maestro» (Quintero 1629: 3). Y también en el epílogo: «Estas dos cosas notó el padre Jacinto Carlos Quintero, clérigo menor, mi hermano, en un sermón, trayendo el lugar de los Cantares» (Quintero 1629: 51v).

Que más de una duda se cierne sobre la identidad (o la clonación) de tales frailes lo sugiere un trabajo de Vidal y Díaz (2007: 551) en el que aduce -sin pruebas- que Jacinto fue clérigo regular en Salamanca y profesor de Teología en el Colegio de San Carlos; además de escribir «bajo el nombre de Benito Carlos [...], el Templo de la elocuencia castellana, Salamanca, 1629, in 4\%». Cabe preguntarse, pues, si la figura del poco prolífico Benito no es sino una superchería literaria. De momento, la Epistola Commendatitia (c. 1634-1642) de Jacinto a los Veteris Hispaniae Dei de Rodrigo Caro es el único testimonio que incluye un dato que podría avalar esa apócrifa creación de un sosias fraterno a la hora de redactar el Templo. En el frontis de dicha carta consta que la escribió el «pater Hyacynthus Carolus Quinterus Clericorum Regularium Minorum quondam apud Salmantinos theologus profesor nunc apud Baeticos publicus concionaton (Pascual Barea 2009: 623). Luego queda muy claro que Jacinto enseñó Teología en el colegio helmántico, estuvo al frente del de Alcalá, fue viceprovincial de su orden y pasó a mejor vida como asistente del provincial. Pero también -siempre según la carta- que «nunc» (o sea: 'por aquel entonces') predicaba sus conciones apud Baeticos, es decir, en Andalucía.

Más discutible, empero, esta conclusión de Pascual Barea (2009: 628):

En 1629 publicó su primera obra en Salamanca y en Sevilla bajo el nombre de Benito Carlos Quintero, donde el seudónimo de Benito (Benedictus) parece motivado por el bene dicere propio del orador, en una especie de juego etimológico con el tema tratado. [...] En Sevilla, el 7 de junio de 1629, cuatro días antes de la licencia, firmó la aprobación del libro Juan de Robles, quien elogia la facilidad de estilo y suavidad de lenguaje de [...] Quintero -a quien todavía llama Benito- en una obra suya aprobada en 1631 precisamente por su amigo Rodrigo Caro ${ }^{7}$.

Sí es meritorio, pero tampoco categórico, su intento de acreditar que Jacinto se acogió a los mismos ejemplos en la Epistola Commendatitia y en el Templo de la elocuencia castellana; sobre todo a los Padres -con Tertuliano y Símaco a la cabeza-, "no solo como intérpretes de la doctrina cristiana sino como modelos de estilo» (Pascual Barea 2009: 630). Por otro lado, las cuatro columnas sobre las que se erige este Templo - propiedad, claridad, adecuación y adorno- y la alegoría poética de la apicultura asoman también por la misiva en latín: «[Quintero] se basa en el doble sentido de cera, del panal y de la tabla donde escribe; de legere aplicado a recoger la miel y a "leer", y de las flores que representan además el ornato literario» (Pascual Barea 2009: 632).

7. Su premisa exigiría, como mínimo, el complemento de este párrafo de Muñoz (1780: IX, 408): «El doctor Benito Carlos Quintero, en el Templo de la elocuencia castellana, [...] dice: "Censura ásperamente esta vanidad el doctísimo Padre Fray Luis de Granada, Cicerón español y espejo de predicadores”». Véase también Salazar y Castro (1714: 151). 
En el discurso I del libro que nos traemos entre manos, su autor -sea el que fuere- dejó escrito: «Vivamos con la pureza antigua y hablemos con la policía nueva; que de esa suerte (como abejas diligentes en el panal de Sansón) juntaremos a las costumbres de cera blandas, puras, inocentes, la miel de la elocuencia usada, siendo en nuestra elección acertados y en nuestro lenguaje advertidamente cuerdos» (Quintero 1629: 6r). Muy poco, sin embargo, para dar fe del extraño fratricidio de un fantasma. No en vano, Herrero-García (1942: 12) defendió la conveniencia de separar a Benito de la alargada sombra de su hermano: «[a Jacinto] atribuyó el Templo de la elocuencia Nicolás Antonio, bien por error, bien porque hubiese llegado a sus noticias que el verdadero autor del libro no era el que aparecía en la portada» ${ }^{8}$.

\section{LOS PARATEXTOS}

Tras la aprobación de Robles y la licencia de Venegas de Figueroa, nos topamos con la dedicatoria de Quintero a Alejandro Grimaldo, dominada por una prosa algo hinchada y el uso de imágenes de cuño emblemático (el sol como símbolo de Apolo, el águila de Júpiter, etc.):

A los rayos del sol, cuando más ardiente pisa con plata presurosa los espacios del cielo, enseña la erudición atenta que saca el águila de Júpiter sus hijuelos, aún faltos del aseo y gala de las plumas, para examinar en la fuerza de su vista la verdad de su aliento. Y a los rayos de su ingenio de vuestra merced saco yo este primer parto, hijo de mi cuidado, para que, amparado de su benignidad y favorecido con su luz, logre, por habella mirado, los aplausos que por sí no merece, y aunque era seguro que le había de consagrar a sus aras de Vuestra Merced, sol que yo tanto estimo por sus prendas (Quintero 1629: 3).

Recuérdese que desde finales del siglo XVI las colecciones de empresas habían sometido las gastadas imágenes humanistas a «un proceso de [...] reversión de su [significado]» para que «la función-poder [se convirtiese en] la materia verdadera del discurso emblemático» (Rodríguez de la Flor 2012: 118 y 121). De ahí que, como he apuntado junto a Tanganelli (2013: 27-28) en otro lugar, el repertorio de Hernando de Soto (1599) viniera enmarcado por la epideixis del duque de Lerma, al que ensalza en la última de sus res pictae con el mote Praemium serui fidelis (Premio del fiel criado): «homenaje de extremada lisonja que le atribuye la divisa del sol» (López Poza 2011: 247), un símbolo político "normalmente reservado para el poder y patronazgo del monarca» (Sieber 1998: 103)9 .

8. La conjetura de Nicolás Antonio fue aceptada por Hermenegildo Dávila, Ruiz y Madrazo (1849: 58) y Cejador y Frauca (1972: IV-V, 95).

9. Tanganelli (2011: 279-341) ha subrayado el peso de la emblemática y la descripción en Pedro de Valderrama (Sermón cuarto en la festividad de la Asunción de Nuestra Señora) y Luis Pueyo y Abadía (Sermón sexto en sesenta y tres símbolos del Mundo simbólico aplicados a las glorias de mi ángel santo Tomás), por citar dos ejemplos. A lo largo del Templo de la elocuencia castellana, he registrado cinco préstamos emblemáticos: 1) «Cayo César [...] juzgaba que no se había de 
Se trata de la misma imagen, esta del sol, que el autor del Templo reservó para Grimaldo, notable descendiente de una «casa ginovesa antigua, conocida, señalada por sus hechos y por los que con armas, letras y dignidades la han crecido luces» (Quintero 1629: 4), a cuyo ingenio este «nuevo polluelo» brinda sus discursos. Pero la alegoría se refina al descubrir que la rapaz, marca aquí de humilitas auctorial, además de símbolo de Júpiter, queda connotada -y casi topicalizada- de forma conceptuosa en otros textos barrocos. Pienso en un romance de Góngora («Ave del plumaje negro», 1622) que, siete años antes de la publicación del Templo, sugiere un trato clientelar no muy distinto a este del salmantino con su caballero ligur: «Ave del plumaje negro, / si bien de tanto esplendor / que, despreciando sus rayos, / vuestras plumas viste el Sol: / no por vuestra beldad sola / reina de las aves sois, / sino porque ministráis / armas que fulmine Amor» (vv. 1-8) (Góngora 1998: II, 521-525). Y lo mismo en uno de los sonetos ("Clarísimo marqués, dos veces claro») del ciclo que don Luis dedicó a los marqueses de Ayamonte entre 1606 y 1607: "¿qué águila, señor, dichosamente / la región penetró de su hermosura / por copiaros los rayos de su frente?» (vv. 9-11) (Góngora 2000: I, 243-244).

Luego este gesto emblemático del «hijuelo del águila de Júpiter» andaba ya algo desplumado cuando Quintero dedicó su retórica. Es obvio, además, que en el Templo de la elocuencia castellana esa imagen encierra tanta modestia como la lícita ambición de remontarse hasta el Sol (Grimaldo) que lo honraba con su mecenazgo, procurándole las prendas («sus rayos sean aplauso que me los gane públicos», 1629: 3-4) para alcanzar celebridad ${ }^{10}$. Basta consultar la empresa Signa fortium (Las armas de los fuertes) de Alciato, en traducción de

huir menos una palabra de estas que el piloto diestro, en un mar inquieto, reconocido a sus peligros, huye el escollo duro en que se deshace la pompa artificiosa de su nave» (Quintero 1629: 10r); inspirado en el emblema 48 de Alciato; 2) «Vio Luciano un retrato del animoso Hércules en que le pintaban anciano, venerable, vestido de las pieles del león nemeo, y desconociéndole en unas cadenas delicadas de oro que, naciendo en su lengua, prendía los oídos de mucho número de gente y la gobernaban a su albedrío" (Quintero 1629: 20r). Su modelo es ahora el emblema 180 del humanista lombardo (Eloquentia fortitudine praesentantior), que Robles (1992: 128) también incluyó en el diálogo III del Culto sevillano: «Y de Hércules se significó lo mismo, [...] que fue pintarlo en su traje ordinario, con su piel de león y su clava, pero muy anciano, y pendientes de la lengua muchas cadenas de oro muy sutiles, con que llevaba presa mucha gente por las orejas»; 3) «Sean, pues, mariposas que sus círculos los dediquen a la claridad de la luz, que a este morirá su ignorancia y vivirá su acierto» (Quintero 1629: 28v); recuerdo de la pictura de Simeoni «Così vivo piacer conduce a morte». Véanse Bonilla Cerezo y Tanganelli (2013: 75-78); 4) «como en la tórtola de los Cantares, que con dulzura de voz junta llano amoroso» (Quintero 1629: 49v); evocación del emblema 62 de la centuria I de Sebastián de Covarrubias; y 5) «Bueno es el consejo de Lipsio que, escribiendo Adversios dialogistam, enseña, con el ejemplo de la peña o escollo herido de las aguas, a vencer sufriendo, y con eso [a] quebrar las ondas del atrevimiento mordaz» (Quintero 1629: 52r). Una res picta semejante se localiza en las empresas de Girolamo Ruscelli (1584, III, fol. 490r.).

10. Al final de la obra, en un alarde de interesadísima modestia, parece olvidarse de lo dicho en la dedicatoria: «que me inspiró la pluma el vuelo de estos discursos, no ambición de aplausos, pues no los merece» (Quintero 1629: 52v). 
Daza Piciano (1549: 112): «Digo que como yo soy la más fuerte / entre las aves, ansí a este es dada / de los héroes la más alta suerte» (vv. 4-6).

¿Cómo juzgar si no, por humilde y paniaguado que fuera Benito Carlos, su arbitrio de difundir el Templo en su rincón nativo y también a varios cientos de kilómetros de distancia? Sin perder de vista el papel de los sermones -y de los manuales eclesiásticos- como vehículo de prestigio social. García Martínez (2006: 89) ha evidenciado que de los más de 1200 impresos en Sevilla en el siglo XVII, cerca de la mitad llevan en la portada una dedicatoria, de las cuales las dirigidas a título invididual «representan más del $90 \%$ [...], encontrando en ellas tanto a eclesiásticos como a laicos [...] que se [identificaron], plenamente, con estas prácticas, gustando de aparecer en las portadas [...] a modo de reconocimiento». De hecho, una buena parte de la alta nobleza sevillana así lo hace. Y Alejandro Grimaldo, que regentó un próspero negocio de contaduría junto a Antonio Espínola, y en 1629 oficiaba como correspondiente en la capital andaluza del genovés Lelio Invrea, tras haberlo sido (1624-1629) de Nuño Díaz Méndez Brito, Vincenzo Squarciafico, Ottavio Centurione, Stefano Spínola, Gio Gerolamo Spínola y Paolo y Agostino Giustiniani, no iba a encarnar la excepción ${ }^{11}$. Asimismo, «el ejemplo de la Monarquía era [...] referente obligado para todo noble castellano, del que tomaban pautas -y emblemas: el Sol- de comportamiento» (García Martínez 2006: 89) ${ }^{12}$. Ni el fraile ni el banquero desaprovecharon, pues, el espacio que podía brindarles una mutua proyección, por vía retórica, que resaltara su linaje («casa ginovesa antigua...») tanto como sus bolsillos.

No obtante, la dedicatoria del Templo de la elocuencia castellana destaca por la primera de sus citas, extraída del diálogo De benefitiis de Séneca, filósofo al que Quintero se referirá más de una vez:

Fineza es que arguye amor, en opinión de Séneca, este solícito apresurarse; pues, como reparó en lo de Benefitiis, quien tardó en dar mucho tiempo, no quiso dar, agraviando con la detención su liberalidad y con las dudas su franqueza: Qui tarde dedit, diu noluit (Quintero 1629: 3-4).

Como ha observado Galbarro (2010: 84), a lo largo del Templo el rétor tiende a «ejemplificar especialmente con Cicerón, Virgilio y Séneca [y muestra] una postura mesurada respecto al conceptismo"; pero también hay que notar que Chacón lo compara en su décima con Orfeo («Tantos los aciertos son / que en tu Templo culto veo / que vulgar parece Orfeo / y plebeyo Cicerón», vv. 1-4) (Quintero 1629: 1) e Infante de Olivera ("Clicie, al sol enamorada») le dio el título de «Demóstenes español» (v. 8) (Quintero 1629: 1). A la luz del triunvirato de autoridades reseñadas por Galbarro, quisiera reflexionar ahora sobre otra característica del estilo de Quintero, relativa no tanto a la polémica gongorina cuanto a los cambios que se produjeron en los manuales de retórica a lo largo del último cuarto del siglo XVI.

11. Véase Álvarez Nogal (1997: 129).

12. El paréntesis dentro de la cita es mío. 
Si el salmantino apostó en estos dos discursos por conciliar el elogio de Góngora con la censura de los barbarismos que se deslizaban entonces por nuestro idioma, también supo nadar y guardar la ropa a la hora de mojarse sobre las escuelas oratorias que habían rivalizado durante el Renacimiento: los ciceronianos y los ramistas. López Grigera (1994: 49-60) ha cartografiado esta disputa como uno de los hitos del Quinientos español, aunque en la Península nunca llegara a darse un ciceronianismo a ultranza, fruto quizá de la fuerte corriente erasmista que imperó en la corte de Carlos I. Desde la otra ladera, el ramismo, como se sabe, defendía

el abandono del periodo -que avanza por relaciones de prótasis y apódosis- usado preferentemente por el estilo sublime. Al mismo tiempo, se revalorizaba el estilo "ático" y se cambiaba el canon de autores imitables: los de la Edad de Plata romana sustituían a los de la Edad de Oro. Séneca se presentaba como modelo, no solo en el pensamiento, sino también en el estilo (López Grigera 1994: 54) ${ }^{13}$.

Quintero se muestra algo tibio sobre este asunto, o sea, el reemplazo de un canon por otro -lo veremos enseguida-. Leamos como adelanto un párrafo del primer discurso del Templo, suma barroca y llena de sal de ese debate entre aticistas y asianistas:

Estilo fijo es razón que escoja el elocuente pero, si mi gusto tiene voto, de mejor gana me inclinara al ímpetu corriente y no afectado de Cayo Graco, o a la madurez de Lucio Craso, que a los rizos de Mecenates y a los repiques de Galión; ¡cuánto pareciera mejor el orador con un vestido áspero que con uno afeminado y lascivo! Pues el estilo que muchos entendidos vanamente siguen no solo no es de oradores, pero ni digno de hombres, porque su blandura de palabras, su facilidad liviana de sentencias y la libertad lasciva de su adorno parece estampa viva de farsantes o imitación de la delicias de un danzante sensual y profano (Quintero 1629: 19v-20r).

Aviso que las cosas no fueron tan sencillas como parecen. Y concedo que se me podrá objetar que esa cita de Séneca en la dedicatoria del Templo no era de naturaleza estilística, sino moral; luego de poco vale a efectos retóricos. Pero tampoco se desprecie, por un lado, el interés de Quintero en conciliar la retórica de Cicerón con la del autor de las Consolaciones; y por otro, la pujanza que cobra el estilo y hasta el número de citas de Séneca en el discurso para el uso de predicadores, justo cuando el doctor nos explica cómo deben hablar; sin condenar por ello, en ningún momento, el sistema del maestro de Arpino.

Ya dentro del campo de la homilética, Quintero (1629: 4) declara que

ofrezco a Vuestra Merced estas primicias de mi cuidado, a que me despertó la pluma cuando dormía el sueño de menores letras, con la censura cuerda que dio a la elocuencia

13. Sobre el ramismo, véase todavía Ong (1958). Tengo presente, además, la tesis de Meerhoff (1986), quien reformuló las relaciones entre ramismo y ciceronianismo o, mejor, del «auténtico ciceronianismo de Ramus», desmintiendo la imagen, admitida hasta entonces, de Ramus como detractor de Cicerón, a juzgar por sus Brutinae Quaestiones (1547). Hago mías las siguientes palabras de Luján Atienza (2003: 297-302): «me propongo aquí dar cuenta de cómo ciceronianismo y ramismo colaboran de otra manera, en un nivel más profundo del sistema ramista; a saber, intento explorar cómo el método de Ramus es visto, en términos pedagógicos, como el medio más apropiado para llegar a la imitación ciceroniana que se practicaba en las escuelas y universidades del siglo XVI». 
de estos tiempos y sus predicadores, en que yo entonces dije mi sentimiento sin apoyos, y ahora le pongo los de la Escritura, Padres, filósofos gentiles y poetas, porque un autor incierto no niegue a la verdad cierta los créditos que gana por sí mesma.

El apunte que reza «la censura cuerda que dio a la elocuencia de estos tiempos y sus predicadores» y el revelador inciso de que antaño siempre "había dicho su sentimiento sin apoyos», decantándose en el Templo por argumentarlo todo con lugares historiales de la Biblia, de la Patrística e incluso de los poetas áureos, anticipan la cuestión más palpitante de nuestra oratoria: la ofensiva de los antiguos - «humanistas rezagados» los llamó Blanco (2002) - contra la difícil modernidad.

Así, no parece casual que el mismo año en el que Quintero publicó su retórica, Pedro León y Moya diera a la estampa sus Aforismos y reglas para más bien ejercer el alto oficio de la predicación evangélica según doctrina de santos y escritores antiguos y modernos (Antequera, Manuel Botello de Payva, 1629), que coinciden en varios puntos con el arte del salmantino. A grandes rasgos, los aforismos de este mínimo andaluz inducen a los oradores a buscar su estilo, ahondando en los métodos para "evangelizar más llano», a imagen de los santos y de los sabios. La segunda sección del volumen gira -igual que el Templo de la elocuencia castellana- en torno a las "calidades y partes del orador", mientras que la cuarta explica la invención, elección y disposición del discurso. De mayor fuste son la quinta, en la que León se ufana de no necesitar muchos lugares de las Escrituras, la sexta ("Del estilo que se ha de guardar y de la observancia de las consideraciones especulativas o morales») y la octava ( lenguaje, del modo de decir y de sus acciones»). Y es que el mismo fraile que decretara con gracia que los predicadores no podían ser «monstruosamente feos» (León y Moya 1629: 7), abogó también -como Quintero- por omitir las voces extranjeras en el sermón; amén de desmarcarse del gongorismo en los púlpitos, aun consintiendo, pero solo en los lugares justos, el empleo de fábulas, jeroglíficos e incluso versos.

He reparado antes en el sintagma "censura de la elocuencia» y en los lugares historiales, o bien en la falta de ellos, porque prendieron la mecha de otra de las guerrillas del Barroco. Me refiero a la que sostuvieron in absentia, con un hiato de más de diez ańos arbitrando su mutuo desprecio, el jesuita José de Ormaza, autor de la Censura de la elocuencia (Zaragoza, 1648), que publicó bajo el seudónimo de Gonzalo Pérez de Ledesma, y el también miembro de la orden ignaciana Valentín de Céspedes (alias Juan de la Encina), responsable de Trece por docena (c. 1659), que hubo de correr manuscrito. Esta batalla oratoria - a la que pronto se alistaría Ambrosio de Bondía (Triunfo de la verdad sobre la Censura de la elocuencia, Madrid, Juan Martín de Barrio, 1649)- ha sido estudiada ya por Blanco (2002), lo que me exime de glosar en exceso las posturas de estos dos enemigos íntimos, respectivos ejemplos de los oradores modernos y de los antiguos.

Sí subrayaré que Quintero, al comienzo de su Templo, se resiste a dar a los antiguos más crédito del debido, marcando también «el límite máximo 
de sensata flexibilidad que podían alcanzar las concepciones más avanzadas sobre la predicación [...], desde la base del más indiscutible entusiasmo por los logros poéticos del espíritu y la sensibilidad barroca» (García Berrio 1980: 214218). Parto además de la premisa de que, una vez leídos los pioneros libros de Herrero García (1942) y Smith (1978), los eruditos de Cerdan (1994a, 1994b) acerca de Paravicino, y la bibliografía del mismo Cerdan en el monográfico que coordinó para la revista Criticón (2002) ${ }^{14}$, nuestros problemas no radican tanto en que el Barroco hispánico diera lugar a una colosal hornada de rétores teñidos de gongorismo -valga la imagen-, ni tampoco en que se trate del capítulo peor conocido de la prosa áurea -ahí están las cuidadas ediciones de Ledda y Stagno (1985), Soria Ortega (1991) y Cerdan y Laplana (1998) para refutarlo-, cuanto en que hemos desoído a varios de los precursores de esa trifulca entre Ormaza y Céspedes; al igual que a más de uno de sus epígonos ${ }^{15}$.

Baste mencionar a Pedro León y, claro, a Benito Carlos Quintero, entre los primeros, y a Martín de Velasco, autor del Arte de sermones para saber hacerlos y predicarlos (Cádiz, Bartolomé Núnez de Castro, c. 1675, licencia con fecha de 1677), franciscano y Padre de Provincias en Santa Fe de Bogotá, entre los segundos. A este último lo rescaté en un largo trabajo (Bonilla Cerezo 2012) donde sugería que Velasco no afiló todas las saetas que el muy conservador Céspedes, nieto a la sazón del Brocense, había disparado contra el díscolo y original treintañero que debió de ser Ormaza, sino que participa de los juicios de ambos sobre el estilo. Luego mi objetivo también se cifra en leer el Templo de la elocuencia castellana como un preludio de ese duelo jesuítico. Sobre todo por lo que atañe al gongorismo ${ }^{16}$.

A ver si me explico. Según las geografías y las cronologías, dos factores a tener muy en cuenta, la polémica sobre los cultismos y la falta de decoro de las Soledades se irradió desde la elegante Sevilla de los años veinte del siglo XVII, «nueva Roma del Humanismo» (Lleó Cañal 1979) por la que triscaban Jáuregui y casi con plena certeza Quintero, al no menos fino virreinato de Perú, donde Espinosa Medrano publicaría su Apologético en 1662, sucediéndose a plumas forzadas las opiniones a favor y en contra de las silvas de don Luis. Toda una cáfila de ingenios, en definitiva, que vinieron a poner orden y más de un paño caliente -o frío- en los dimes y diretes de dos batallas vecinas. Podría esquematizarlos así: Ormaza (= Góngora) vs Céspedes (= Jáuregui); y Quintero, León y Robles (precursores entre 1629 y 1631 del futuro rifirrafe entre aquel par de jesuitas).

Con otras palabras: en su Censura de la elocuencia (1648), el padre Ormaza sancionó una práctica sermonaria sin lugares bíblicos ni citas que trabaran las

14. Véase también Núñez Beltrán (2000).

15. La monografía de Tanganelli (2011) ha colmado buena parte de estas lagunas. Remito al capítulo «Ormaza e la terza polemica barocca. Verso una retorica de la descriptio» (pp. 27-133).

16. Artaza (2000: 45-66) puntualiza, no obstante, que del tratado de Quintero queda todavía excluida la violencia que revestirá posteriormente la polémica sobre el empleo de agudezas en el discurso sacro: «El [...] salmantino se limita a declarar que el mayor perjuicio que el predicador puede causar a las almas es el abuso en el empleo de las sutilezas que, buscando "la novedad del pensamiento (...), tuercen (...) la Escritura”». 
conciones: un invento, pues, «radicalmente literario, en su tránsito del binomio enargeia / movere a la pareja ekphrasis / delectare» (Tanganelli 2008b: 125; 2012); libre de esas muletas a las que tan aficionados habían sido sus mayores: León, Quintero y Céspedes. Así, de acuerdo con la clasificación de Díaz Lavado (Herrero Salgado 2002: 64), José de Ormaza sería el primero en prescindir de la retórica como «texto citante» y en pasar a un segundo plano las autoridades, embutiéndolas, o bien disipándolas, dentro del sermón ${ }^{17}$.

Admito que Quintero nunca sobrepasó ciertos límites, aferrándose a un conservadurismo retórico - por lo que toca al uso de los lugares- en la línea de lo que cuatro décadas más tarde haría Céspedes, humanista pucelano en el que «no hay vanidad erudita en la cita, sino honesta labor filológica, amor a la verdad depositada en el tesoro de las letras [...] y cristiana humildad de quien se inclina ante el texto inspirado» (Blanco 2002: 141). Sin embargo, nada obsta para juzgar al responsable del Templo de la elocuencia castellana como uno de los primeros que acortaron la distancia entre el prodesse y el delectare. Escribe el doctor, citando a Horacio y a san Agustín: «la oración no ha de ser solamente fuerte, que sus palabras descubran la verdad sin más adorno, sino importa que a la necesidad sobrevenga la gala que deleite, [...] convidando no solo a ella sino con flores de palabras elegantes, cultas y retóricas» (Quintero 1629: 39r). Y apostilla: «el púlpito pide [...] un mixto de tres cosas diversas, que son enseñar, deleitar y persuadir; y como es culpable el predicador en faltar al deleite, también lo es entregarse tanto a él que olvide la parte de enseñar al pueblo» (Quintero 1629: 43v) ${ }^{18}$.

No tengo dudas tampoco de que para nuestro salmantino, a la altura de 1629, la retórica civil formaba ya parte del pasado, reducida a un venerable cajón de figuras del que extraer alguna joyita: "porque las [palabras] afectadas con voces poéticas y metáforas, o translaciones afeminadas, no convienen al orador civil, cuantimás al predicador ejemplar» (Quintero 1629: 43r); de ahí que nos legara, en cambio, una retórica eclesiástica, un arte para los púlpitos, que en la segunda parte - por la que sobrevuela la sombra de san Agustín- no llega a borrar del todo uno de los pilares del quintilianismo: la utilidad por encima de los hechos narrados ${ }^{19}$.

17. La preeminencia retórica del delectare había sido avanzada por Gaspar Salcedo de Aguirre en «XII. Letra para un sacerdote que quiere començar a Predicar: en que aviéndose tratado de los tres officios principales del Predicador, se le dan algunos avisos: finalmente se trata de las partes del sermón: y de la pronunciación o acciones del Predicador», incluida en su Pliego de Cartas en que ay doze epistolas escritas a personas de diferentes estados y officios..., Baeça, por Iuan Baptista de Montoya, 1594, fols. 172v-204r. Véase también Tanganelli (2008a: 57-106).

18. Subrayo su tendencia a la ambigüedad, e incluso a la contradictio, ya que al final del discurso segundo, Quintero (1629: 46r) censura «este negro deseo de dar gusto en los púlpitos». Recuérdese que el auge barroco de la inventio y el delectare, como sustitutos de la imitatio y el docere, derivó de la posibilidad de conciliar la oscuridad y el deleite -opción a la que no se atreverá Quintero-. Así lo explica el abad de Rute en su Examen del Antídoto (1617). Véase al respecto Roses Lozano (1994: 145-151).

19. Gunderson (2009: 118) opina que «rather than presenting a "rhetoric of fact", Quintilian instead prefers to evoke the idea of "utility"". 


\section{DISCURSO PRIMERO}

La planta de los discursos que forman el Templo de la elocuencia castellana, en donde, como procuraré mostrar, «se puede leer mucho más de lo que el autor expresa con palabras» (Martí 1972: 291), resulta bastante sencilla. «Obra seria, [...] erudita (112 citas de 39 autores, sagrados y profanos), bien escrita, pretendidamente literaria, de fácil y agradable lectura» (Herrero Salgado 1996: 231), Quintero divide el primero (36 fols.) en cinco puntos que moldean las cuatro columnas sobre las que funda su retórica: «propiedad, adorno, claridad y decir acomododadamente»; al objeto de «limpiar el oro de nuestra lengua [...] de las malas impresiones que la ofenden» (Quintero 1629: 1r).

\section{La nueva elocuencia}

Está claro que sus tesis beben de los artes narrandi que Elena Artaza ha fatigado con tiento, empezando por el de Cicerón, que distinguía tres cualidades en el orador: «brevedad», «claridad» $\mathrm{y}$ «verosimilitud» ${ }^{20}$. La última, semejante a la «credibilidad» de la que hablara Aristóteles, viene definida por la necesidad de que tanto los datos como los hechos estén en consonancia con la naturaleza de sus autores y las creencias de los oyentes (Artaza 1989: 49). Lo que, mutatis mutandis, parece bien resumido en el «decir acomodadamente» del Templo.

Eso sí, como El culto sevillano de Robles (1992: 130), que abogaba por una lengua pura, clara, adornada y acomodada, Quintero pudo inspirarse para este último concepto en las ideas del salmantino Baltasar de Céspedes, aun considerando que sus Obras no circularon impresas (Del arte de la retórica está fechada en 1597 $)^{21}$. Otro detalle que el Templo de la elocuencia comparte con el humanista castellano es que este abría su capítulo sobre la pureza con un símil («y así como las monedas corren por el consentimiento o prohibición del pueblo, así el lenguaje se admite o desecha por el uso del mismo pueblo llano», Gómez Camacho 1992: 21) que Quintero (1629: 17r) relee de esta forma: «esto es lo aplaudido, la moneda falsa que hoy corre y lo que venera la ignorancia por no descubrir que no lo entiende». Y no se olvide que el «decir acomodado» tampoco resultaba nada extrańo en la oratoria humanista de

20. Sobre los exégetas de Cicerón en el Quinientos, véase Ward (1999). Fumaroli (1999: 308) destaca que el éxito de conceptos como «elegancia», «urbanidad», "amable y amena simpatía» y «agudeza» en los artes del Siglo de Oro tiene por modelo las Epistolae de Cicerón, mucho más que sus Orationes. Lo confirma el segundo punto del primer diálogo del Templo de la elocuencia castellana, aquel en el que Quintero (1629: 11v) se resiste a adoptar neologismos gratuitos: «habían los cuerdos de hacer con sus poemas lo que cuenta Cicerón de Aristarco, escribiendo a Apio, en el libro 13 de sus Cartas, que era tan amigo de las dulzuras y majestad de los versos de Homero que, cuando en ellos veía algún delito semejante a este o alguna impropiedad, apuntaba aquel verso, creyéndole no de autor tan acertado sino introducido por algún ignorante».

21. A tenor de los manuscritos (el de la BNE con signatura 2327, compuesto de 55 fols., y el II/1004 de la Biblioteca de Palacio, pp. 139-333) que han llegado hasta nosotros y de las citas y referencias de sus coetáneos, hay que pensar que gozó de popularidad. 
mediados del Quinientos; por ejemplo, Mateo Bossulo, miembro del círculo valenciano, declara que el ars bene dicendi se define como «un hablar adornado, bien compuesto, y acomodado a la diversidad de los oyentes» (Luján Atienza 1998: 36).

Respecto a las otras cualidades, Quintiliano explicó la brevitas como "no decir más de lo necesario» (Artaza 1989: 72-73), y acaso esta sea la horma sobre la que el salmantino acuñó su idea de "propiedad». Solo faltaría, pues, precisar el correlato clásico para la voz "adorno», según la emplea Quintero. Creo que de nuevo se localiza en la Institutio, bien es verdad que como secuela de otra de las cualidades del segundo género de discurso: el admirabile -el tercero, como se sabe, es el anceps-. Cuando el rétor de Calahorra explica qué tipo de narración beneficia a las causas del status qualitatis, distingue los asuntos pequeños (genus humile) de los principales. Acerca de los primeros, aconseja "el adorno de las palabras, composición y uso de figuras, ya que lo que se oye con gusto resulta más creíble» (Artaza 1989: 83); mientras que para los otros recomienda «el cuidado del tono en el decir y el empleo de apotegmas» (Artaza 1989: 84).

Cualquier aficionado a la retórica sabrá que estas cuatro cualidades de las que vengo tratando se perpetuaron en los artes de Trebisonda, Vives y Salinas. Más interesante, en cambio, el de García Matamoros, antepasado lejano del Templo de la elocuencia castellana. La segunda obra de este gramático, De tribus dicendi generibus sive de recta informandi styli ratione commentarius cui accessit de Methodo concionandi (Alcalá, taller de A. Angulo, 1570), la componen dos libros: un tratado sobre el estilo y un manualito para predicadores. Incluso coincide con Quintero en sus dudas sobre si imitar o no a Cicerón (Artaza 1989: 135). Andando el tiempo, aparecerían el De arte rhetorica libri III de Suárez, que fusiona las opiniones de Aristóteles, Cicerón y Quintiliano; la Prima pars rhetoricae de Palmireno ${ }^{22}$; el Rhetoricorum libri IV de Arias Montano, la Rhetorica Ecclesiastica de fray Luis de Granada -nuestro salmantino la cita un par de veces: «Tiene la retórica cuatro como columnas en que estriba y se funda el templo hermoso de la elocuencia, como Cicerón, Quintiliano, fray Luis de Granada y todos los que de esta materia afirman» (Quintero 1629: 6v)- y otras muchas hasta la llegada del Barroco.

Al socaire de todas ellas, podemos avanzar ya algunas conclusiones: 1) más que una retórica stricto sensu, Quintero redactó un pequeńo esbozo sobre la elocutio $^{23}$; consciente de que «la teoría del estilo establece el vínculo entre retórica y poética» (Plett 1999: 421); 2) su decisión lo aproxima a los ramistas, que consideraban la elocutio una fase instrumental de la retórica al servicio de la inventio, hasta el punto de suprimir esta última (junto a la dispositio) como

22. Remito al trabajo de Ángel L. Luján Atienza en este número de Bulletin Hispanique.

23. Según Mohrmann (1999: 77), «el interés del antiaristotélico Ramus no fue el del discurso, pero cuando se formó la lógica de su reforma intelectual, la invención y la disposición procedieron de la retórica. Ramus no ligó su nombre a ningún tratado de retórica, pero sí lo hizo su discípulo Talón, y es en esa obra en la que encontramos esta formulación concreta: "el mandato de que el estilo y la exposición son el todo de la retórica"”. 
partes del arte; y 3) aunque el doctor salmantino no se muestre tan cartesiano como Aristóteles, al que no menciona ni una vez, Cicerón, Quintiliano y el coro de palmeros de uno y otros en el siglo XVI, sí tiende a enfatizar el delectare como algo indisociable del prodesse y la credibilidad.

Por lo que toca al templo que da título a esta preceptiva -iqué otra cosa es una retórica!-, podemos juzgarlo como algo singular, aunque su brillo se apaga un poco al reflejarlo sobre otros textos del Siglo de Oro. Quintero eligió un icono arquitectónico como hilo conductor de su narratio; pero una vez cruzada la puerta de entrada, oportunamente guiados a lo largo y ancho de las cuatro naves de su edificio teórico, nos queda el regusto de que solo ha copiado una cornice de aquel tiempo. Nótese que ni siquiera describe con tecnicismos (pilastra, dosel, cimacio, arquitrabe...) las columnas de su retórica. Quizá porque un sinfín de templos se habían alzado ya como clave de bóveda -nunca mejor dicho- de varias obras que aúnan precisamente la arquitectura con la teoría literaria, y esta con la memoria. Solo mencionaré, por no separarme demasiado del libro de Quintero, Las Moradas del Castillo Interior (1577), de santa Teresa; El palacio de la memoria (1596), del jesuita Matteo Ricci; la Retórica sagrada y evangélica ilustrada con la práctica de diversos artificios retóricos para proponer la palabra divina, de Francisco Ameyugo (Zaragoza, 1667); o el Jardin de la elocuencia oratoria, poética y política, de fray José Antonio Hebrera (Zaragoza, 1677) ${ }^{24}$. Es más, al Templo de la elocuencia castellana le encaja como un guante este párrafo de Pedro Mexía en su Silva de varia lección (1540, apud Gerli 1984: 160):

La memoria se puede ayudar y augmentar con arte, es cosa muy cierta y de ello escriben muchos auctores... Para lo cual, para que desto también digamos algo, principalmente se han de ayudar de muchos lugares señalados y muy conocidos, como si en una casa muy grande o camino o calle señalásemos con la imaginación y tuviésemos en la memoria muchos lugares y puertas.

\section{Y este otro de Gerli (1984: 156) a propósito del Castillo interior:}

desde los antiguos más antiguos, el arte de la memoria ha explotado como su artificio favorito la imagen arquitectónica del edificio, sea este palacio, iglesia, castillo o pabellón para estructurar el orden de lo recordado. La posibilidad infinita de añadir o quitar aposentos a un edificio memorístico lo convirtió en la imagen más eficaz para la recolección de las ideas y su organización material ${ }^{25}$.

Puesto que ya he revelado el papel de calco de este tópico, convendrá entrar en harina. Quintero inaugura su discurso con unas pinceladas sobre la lengua de los antiguos y la de los modernos. Partidario a marchamartillo de las plumas áureas y del idioma como instrumento en continuo cambio, refuta la idea de «venerar siempre lo pasado por poco conocido y despreciar por tratado lo presente» (Quintero 1629: 1v).

24. De Hebrera y Esmir se ocupa Andrea Baldissera en este mismo volumen.

25. Véanse con mucho mayor detalle Rodríguez de la Flor (1988) y Bolzoni (2007). 
Desde el principio, al comentar un epigrama de Marcial a Régulo (lib. V, epig. 9), acude a un pequeño canon de clásicos para fortalecer su postura:

Por eso, ingratos, buscamos la sombra del perdido Pompeyo, y alaban, habiendo tan buenos edificios modernos, los templos viles de Catulo. Enio es leído, Virgilio, despreciado; siendo aquel, en su vida, risa de la elocuencia, y este gloria. A Menandro, que mereció coronas, le aplaudieron raros teatros, y a Ovidio le conoció solo su amiga Corina (Quintero 1629: 2r-2v).

El párrafo es corto pero jugoso. Quintero instaura aquí una dicotomía entre los que metaforiza como «templos viles» y aquellos a los que asigna el marbete de "templos elocuentes», o bien el de «teatros» (Menandro), en virtud de su mayor o menor ancianidad. Despliega, pues, un argumentum a contrario: se remonta a los autores grecolatinos para defender a los ingenios de la Edad de Oro. Nótese también su coherencia retórica: el doctor tituló su manual Templo de la elocuencia castellana y enseguida aprovecha, pero muy superficialmente, el léxico de la arquitectura, haciendo gala de lo que Gunderson (2009: 120), al discurrir sobre Quintiliano, definiera como «retórica de la teoría retórica»: «As, then, poetry sweetened philosophy so does rhetoric sweeten rethorical theory».

Otra curiosidad es el primado que Quintero otorga a Virgilio y Ovidio frente a Pompeyo, Catulo, Enio y Menandro. Los dos primeros vivieron en el siglo I a. C. y se los tenía por los mejores y más versátiles poetas de su tiempo, cumbres de un estilo que poco se parecía ya a la elocuencia requerida en el foro -Ovidio fue alumno de Higino, Arelio Fusco y Porcio Latrón-. Por otro lado, al arrimar estas ascuas a la sardina del gongorismo, descubriremos que las Metamorfosis son el "modelo más insistente y manifiesto en el conjunto de la poesía [del cordobés]» (Pérez Lasheras 2008: 139). No en vano, Waley (1959: 193-209) sentenció que "Góngora indica claramente las Metamorfosis [...] como criterio mediante el cual le gustaría que se juzgara y entendiera su obra; ahora bien, en materia de pastoral clásica, dependería más de Virgilio que de ningún otro autor clásico».

Un criterio muy plausible, que debiera matizarse con el de Blecua, quien iluminó el trasfondo virgiliano de la polémica sobre la nueva poesía, en la medida en que al mantuano se lo estimaba desde hacía siglos el bardo por excelencia y «el Polifemo se inspira, desde luego, en Ovidio, [...] pero también en la Eneida (III, vv. 548-681), y las Soledades lo hacen no solo en las Bucólicas y Geórgicas, sino también, y no poco, en la Eneida» (Blecua 2008: 119). A renglón seguido, Blecua (2008: 121-122) puntualiza que "este es el Virgilio que aparece en Góngora; más el Virgilio de la Eneida y de las Geórgicas que el de las Bucólicas». Los dos modernos de la latinidad como referentes de la poesía del fundador de la modernidad. De hecho, a propósito del uso de los adjetivos antepuestos al sustantivo, Quintero (1629: 15v) escribe en el Templo que Góngora «venció a Virgilio, Horacio y Ovidio, con ser tan cuidadosos en el adorno de los epítetos».

Pero no quiero recalar todavía en el gongorismo del salmantino, sin duda algo voluble, porque Quintero le dio a don Luis una de cal y cuatro de arena. 
La mención de Ovidio y más aún la de Virgilio como superiores al viejo Ennio poseen implicaciones que no abandonan el campo de la retórica: según sugiere el doctor, en las primeras décadas del Seiscientos, Ennio (III-II a. C) era ya catalogado como una suerte de Virgilio en bruto; y eso que hablamos del primero de los grandes épicos latinos, gracias a sus Annales. Pues bien, Quintero es un poco injusto, porque calla, mucho más que ignora, que el mismo Ennio había sido un innovador -otro moderno, por así decir- respecto a los poetas previos; sin ir más lejos, sustituyó el anticuado verso saturnio por el hexámetro dactílico de los griegos para el cultivo de la epopeya, cauce por el que transitarían tanto Ovidio como Virgilio. De hecho, al ocuparse de la elocución culta, y en concreto de las metáforas gongorizantes, Quintero (1629: $15 \mathrm{v}$ ) admite que "aun Enio, que hizo bóvedas de los cielos a sus cóncavos, fue reprehendido de la antigüedad escrupulosa».

Ya en la órbita de la batalla sobre los poemas mayores de don Luis, sorprende el parecido -con la novedad de la presencia de Garcilaso- entre el penúltimo párrafo que he citado de Quintero y este del anónimo antequerano que defendió (c. 1615) la Soledad primera:

Bien podemos comparar a Garcilaso al antiguo Ennio, pues cada uno en su edad hizo un mismo honor y argumento a su lengua; Virgilio, oscureciolo, no de otra suerte que D. Luis a Garcilaso le ha oscurecido y sepultado (Osuna Cabezas, 2009: 105) ${ }^{26}$.

La devoción del salmantino por el autor de la Eneida también hunde sus raíces en los debates renacentistas sobre la imitatio, que alcanzaron, como era predecible, a los partidarios y detractores de Góngora. Téngase en cuenta que los teóricos del siglo XVI se guiaban todavía por la senda estética de la Rhetorica ad Herennium, los tratados de Cicerón, el Ars poetica de Horacio y, sobre todo, por la Institutio de Quintiliano, "cuyo virgilianismo no es necesario recordar; y tampoco su actitud hostil hacia los autores contemporáneos» (Blecua 2008:

26. El anónimo autor de la Soledad primera, ilustrada y defendida señala, también acerca de Ennio, que «a los principios, todos los artes fueron rudos e informes, llenos de dureza y escabrosidad; después, por variedad de tiempo e ingenio, se fueron ablandando y cultivando con el cuidado y la diligencia, dejando aquella grosera corteza y rusticidad cambiada ya en blandura, belleza y perfección» (Osuna Cabeza 2009: 100). Carrillo y Sotomayor (1992: 84) lo afirma en términos similares: «Saliole dichosísimamente a Ennio tan atrevida dicha, ocupó lo que le dio lugar su edad. Virgilio no conoció en su profesión primero; Horacio, Propercio entre los encendidos deseos de su Cintia no se olvidó de intentar nuevo camino. [...] ¿̨Nosotros, pues, ¿por qué en estilo nos hemos de conocer menores?». Robles (1992: 133) lo amplificaría a plana y renglón, aunque sin incluir autoridades en lengua romance: «Y esto mismo que vemos y tocamos se ha de considerar en las lenguas, y se verá [...] ejecutado en la latina, porque nació en su principio de las leyes de las doce tablas, balbuciente y tan mal formada que después no se entendía, y fue creciendo poco a poco por sus edades, en que la fueron formando algo mejor Ennio, Plauto y Terencio, y otros, hasta que en los tiempos de Lucio Craso salió ya (según Quintiliano) de aquella estrechura y pobreza, y comenzó a tener caudal, preceptos y método, y preceptores que la enseńasen, entre los cuales dicen que fue insigne uno llamado Plocio. Y desta suerte se fue ampliando y perfeccionando hasta el tiempo de Cicerón y de sus contemporáneos, así oradores como poetas, como fueron el Príncipe dellos, Virgilio, y Horacio, y Ovidio, y otros». 
122). Son las mismas autoridades que le sirvieron como libros de cabecera a Quintero, con la particularidad de que expulsó de su Templo -y es de veras relevante- esa ojeriza que Quintiliano profesaba a los poetas de su siglo. Dicho de otro modo: con su apuesta por los modernos en el discurso primero, Quintero lleva la contraria al gran retórico latino, cuestionando así las fronteras entre lo admisible y lo inadmisible en el estilo (y el respeto) de los modelos clásicos.

Esto sucedió también porque, desde los comentarios de Robortello y Minturno a las obras de Aristóteles, que dieron como resultado exégesis algo personales de los lugares más oscuros de la Poética y la Retórica, fueron ganando terreno la «admiración» y la «novedad» como claves del placer estético. Nacía así una nueva retórica que rompía con el decoro ciceroniano-quintilianista y comulgaba con otra tesis ramista: el deseo de armonizar a los poetas y rétores de la antigüedad con los del Siglo de Oro.

El Templo de la elocuencia castellana acoge, en la compañía de Virgilio, Ovidio, Mena o Lipsio, a los entonces triunfadores Góngora y Villamediana. Quintero acude a ellos, de hecho, ya para alabarlos, ya para criticarlos, en mucha mayor medida que a Salustio, César o Catulo. Sobre este particular, otra vez nos sirve de ayuda Blecua (2008: 122-123), quien expuso que en los listados de autoridades elaborados en el Renacimiento -Quintero firma aquí uno en miniatura- «los [...] clásicos de la Edad de Oro [latina], si no pierden su puesto, $[\ldots]$ admiten a su lado a otros que el hipercrítico Escalígero había anatemizado. Ahora serán Homero, Anacreonte, Píndaro, la Antología griega, Marcial, Lucano, Apuleyo, Séneca, Tácito, Plinio el Joven, Veleyo Patérculo y, entre los modernos, Lipsio y Barclay los modelos preferidos».

Huelga decir que Quintero trasladó y expandió esta nómina hasta los poetas que descollaron en nuestro país desde finales del siglo XVI hasta la floración de la estética culta (Góngora, pero también Villamediana). Y no solo por lo que toca a la elocutio, sino al número de citas dentro de su preceptiva. A lo largo del Templo, el doctor va dando entrada a todas las figuras de la Edad de Oro de las letras romanas: Cicerón (traído en 16 ocasiones), Horacio (11), Virgilio (8), Ovidio (5), Suetonio (2), César (1), Propercio (1), Salustio (1), Arruncio $(1)^{27}$ y Catulo $(1)^{28}$.

27. «Estos vicios uno los despunta descuidadamente y todos los siguen. Y trae por ejemplo a Salustio, insigne escritor de aquel siglo, inventor de algunas voces y frasis que ponía una sola vez u otra en la oración. Arruncio, gran imitador suyo, aquellas mismas las rozaba a cada paso en sus escritos: «Quae apud Sallustium rara fuerunt, apud hunc crebra sunt et pene continua, nec sine causa: ille enim in haec incidebat, at hic illa quaerebat. Vides autem quid sequatur ubi alicui vitium pro exemplo est?» (Quintero 1629: 12v). Considero harto probable que para esta anécdota sobre Arruncio, que consta, en efecto, en las Epistolas a Lucilio de Séneca (XIX, ep. 114 [18-19]), y aquí se aprovecha para glosar una serie de neologismos jocosos, Quintero tuviera a la vista el Discurso poético de Jáuregui (1978: 87-88), que la reprodujo sin diferencias aparentes: «Cuenta que Arruncio, historiador, se inclinaba a las locuciones extrańas de Salustio, y en hallando alguna la amaba y la abrazaba de suerte que la repetía en cada hoja».

28. La presencia de Catulo obedece a que el cantor de Lesbia fue un poeta neotérico, en opinión de Cicerón; o sea, militaba en el mismo grupo que Helvio Cinna, Licinio Calvo, Valerio 
Se imponen con suficiencia los retóricos (Cicerón y Horacio), además de los dos poetas mayores: Virgilio y Ovidio. Muy por encima de la escasísima atención que concede a los narradores y a los historiadores. Pero al margen de estas cifras, todos ellos, según acabamos de leer, relevaron y hasta superaron, siempre a su juicio, a los de la Edad Temprana: Menandro (1), Enio (3), los ya nombrados Cayo Graco (1) y Lucio Craso (1), oradores de los siglos II-I a. C. celebrados por el mismísimo Cicerón, Mecenates (1) y Galión (1), hermano de Lucio Anneo Séneca, hijo de Séneca, el rétor y procónsul de Acaya en tiempos de Pablo de Tarso, al que libró en Corinto de manos de los judíos.

Tampoco vacila a la hora de citar a aquellos clásicos recuperados ( Por eso Homero decía de Ulises: Vocem emittere non ex ore, sed ex pectore» (Quintero 1629: 7r) extracta el pasaje, no obstante, de las Noctes Atticae de Gelio (lib. I, cap. XV [3]) y a los de la Edad de Plata latina de los que hablara Blecua : ya nos hemos topado con Séneca (20), Quintiliano (18) y Marcial (6), pero tampoco faltan Tácito (11), Macrobio (6), Filón (4), Lactancio Firmiano (3), Gelio (2), Luciano (2), Plinio el Joven (2), Apuleyo (1), Dionisio Areopagita (1), Símaco (1), el más raro Curio Fortunato (1) y los primeros Padres de la Iglesia, sobre todo en el segundo discurso: Agustín (12), Jerónimo (5), Juan Crisóstomo (4), Bernardo (3), Cipriano (3), Clemente Alejandrino (2), Crisólogo (2), Gregorio Magno (2), Hilario (2), Tertuliano (2), Ambrosio (1), Basilio Magno (1), Clemente Romano (1), Enodio (1), Gregorio Nacianceno (1), León Magno (1), Orígenes (1) y Paulino (1) ${ }^{29}$. Por último, evoca los nombres $-\mathrm{y}$ a veces también los textos- de humanistas como Justo Lipsio (5), neoestoico a la zaga de Séneca ${ }^{30}$, además de anticiceroniano convencido ${ }^{31}$, Sannazaro (2), fray Luis

Catón, Cornificio, Furio Bibáculo y los eruditos Marcos Terencio Varrón y Cornelio Nepote, caracterizados por su deseo de cultivar una lírica refinada y concisa, de perfecto acabado formal. Finalmente, el contraste entre Menandro (IV-III a. C.), máximo representante de la comedia nueva ateniense, y Ovidio, que dedicó sus Amores a Corina -joven que probablemente nunca existió- y compuso una tragedia titulada Medea, hoy perdida, avanza en paralelo, dentro del teatro, el que Quintero sugiere entre Ennio y Virgilio.

29. Otra prueba en este sentido es que Quintero no alude a ninguno de los clásicos que Azaustre Galiana (2005) señala como los más saqueados en los debates sobre el estilo culto: san Jerónimo, el verso de Horacio "Parturient montes, nascetur ridiculus mus», Aristóteles, Estacio, Licofrón y Petronio. Aunque mi lista procura ser exhaustiva, no ignoro que sería arduo localizar todos los libros renacentistas, cuando no las polianteas sacras, de los que Quintero tomó sus citas. Incluso se echa en falta una base de datos que permita cotejar los autores de las Edades de Oro y de Plata de la latinidad, y también de los siglos XV-XVII, que disfrutaron de más fortuna en las retóricas barrocas. Llamo la atención, por ejemplo, sobre el hecho de que muchos de los Padres que menciona Quintero son los mismos que inspiraron a predicadores como Paravicino para componer más de un panegírico fúnebre, género también cultivado por san Jerónimo y compañía. Véase Blanco (2012: 39-40).

30. Remito a Fumaroli (2002: 152-161).

31. Fumaroli (1999: 308-309) razona cómo «la disputa ciceroniana, que va mucho más allá [en el Renacimiento] del Ciceronianus de Erasmo, se manifiesta como un debate político también. No es una casualidad que Erasmo, padre fundador de la republica litterarum, sea el maestro espiritual de Lipsio, típico ciudadano de la República de las Letras. El anticiceronianismo de Erasmo y Lipsio asume que el intelectual tiene un margen de independencia considerable 
de Granada (1), al que llama «Cicerón espańol» (Quintero 1629: 40v)³2, Mena (1) y Figueroa (1).

Luego el discurso del salmantino se define también por la cantidad y frecuencia de sus autoridades, confirmándose su viraje hacia el ramismo, desde el momento en que el número de citas de ingenios de la Edad de Plata (56) no solo supera a los de la Edad de Oro (44) -el número de lugares de Cicerón y Quintiliano es bastante parejo-, sino que se taracean con los de las plumas renacentistas que he señalado y también con las de los cultos barrocos.

Para dejar clara su opinión acerca del estilo, Quintero (1629: 4v) condena sin ambages "la elocuencia con canas y el lenguaje sin dientes», culpables de no entender cuánto había crecido el castellano desde sus orígenes ${ }^{33}$. Un juicio que se remonta a los autores latinos, concretamente a Cicerón, quien ya en su época declaraba que «se había de preferir el lenguaje nuevo [...] al antiguo y por labrar». Y también a los artes neociceronianos del Renacimiento, ya que Palmireno abogaba -con la vista puesta en el latín- por el desarrollo de la lenguas vulgares, colocando los primeros peldaños de una escalera que después rematará Ormaza en su Censura de la elocuencia -con voces idénticas, por cierto, a las de Quintero- cuando escribe que «como si no hubiera canas ignorantes, a todas dan el grado de maestras» (Pérez de Ledesma 1985: 49).

Sin embargo, el doctor salmantino incurre en una paradoja. Su apuesta por el uso de lugares evangélicos en los sermones y las continuas citas con las que apuntala el Templo de la elocuencia castellana debían hacer de él uno de esos antiguos con los que se había cebado en el primer punto de su retórica. Pero a diferencia de los maestros ramistas, Quintero toma a Cicerón como ejemplo de la renovación lingüística, mucho menos que de la naturalidad expresiva, como era presumible en un altavoz de Góngora y de la adopción de según qué clase de neologismos; matizando, eso sí, que el maestro de Arpino «juzgaba digna de mayor alabanza la elocuencia del uso». Un término («el uso») que reaparecería dos décadas después en la retórica de Ormaza y había marcado parte de la lingüística -y también de la poesía- del Quinientos desde el Diálogo de la lengua (1535) de Juan de Valdés. Ahora bien, cuando dábamos por buena la supremacía en el Templo del magisterio del autor de De oratore, Quintero recupera el prestigio y las Controversias de Séneca:

Marco Séneca, en el lib. de sus Controversias (Controversia I), lo sintió de esta suerte: «Haec natura rei semper citra veritatem est similitudo. Deinde ut possitis aestimare in

respecto al poder monárquico. Esta independencia del ş̧avant está simbolizada en la divergencia de su estilo de la norma ciceroniana».

32. Robles (1992: 136) lo llama "Cicerón cristiano».

33. Quintero, impugnador de la oscuridad sancionada por Carrillo y Sotomayor en su Libro de la erudición poética (1611), coincide sin embargo con el baenense -quien se había basado en una fuente, Firmiano, que también asoma por el Templo-, cuando afirmaba que «cumplimos ya largamente con la obligación en que nos puso Aristóteles, y no nos podrá decir Firmiano: Sapientiam sibi adimunt, qui sine vllo iudicio inventa maiorum probant: "la sabiduría se quitan los que las cosas halladas por sus mayores sin ningún juicio aprueban”» (Carrillo y Sotomayor 1992: 56). Recordemos además que Cicerón juzgó «digna de mayor alabanza la elocuencia del uso y que se habían de acomodar a ella las canas» (Quintero 1629: 4r). 
quantum cotidie ingenia decrescant et nescio qua iniquitate naturae eloquentia se retro tulerit». Esta es la condición de las cosas: ir siempre faltando a la verdad y que la imitación sea más imperfecta para que, de esa suerte, se conozca cuánto cada día van desmayando los ingenios; y no sé por qué mala suerte nuestra, la elocuencia va descaeciendo con una inclinación y rendimiento al vicio (Quintero 1629: 2v).

Estos bandazos argumentativos dejan espacio a continuación a otro de los rasgos que singularizan la retórica de Quintero: la última cita de Séneca es glosada por dos lugares extraídos de la historia de Sansón (Libro de los Jueces, $14-5,14,8)$ :

Apoyo halla esta opinión, a mi ver, en aquel sabido suceso de Sansón. Contentose del agrado hermoso de la filistea y, yendo a celebrar el casamento, al llegar a unas viñas vestidas de hermosura que tenía el camino, sale un león a él, armado de enojo $\mathrm{y}$ de bramidos ("Cumque venissent ad vineas oppidi, apparuit catulus leonis saevus et rugiens»). Trabose con Sansón, comenzó a forcejear el mancebo, a procurar rendille, y sin más armas que la valentía de sus puños, dio muerte a la ferocidad de aquel león soberbio y principio a sus gloriosos triunfos. Volvió acaso después de algunos días por aquel camino, y picado de la curiosidad, buscó el cadáver del léon despiezado; y dice la Escritura que vio en la boca un panal de miel sabroso que la diligencia de un enjambre de abejas iba labrando artificiosamente: "Declinavit ut videret cadaver leonis et ecce examen apium in ore leonis erat et favus mellis».

Si no hubiera puesto la doctrina antes, no era el enigma fácil; [...] eso es lo que engañosamente hace estimada la elocuencia, la opinión enseñada, aun en los entendidos, a venerar lo que fue y no es, y a despreciar lo que es y no ha llegado al no ser. Pero, si atentamente se repara y examina, león era vivo, que bramaba o rujía, el que hoy, sin más limas que la falta de vida y el polvo ciego del sepulcro, le hace venerado en su panal, en su miel, en su dulzura y sus escritos (Quintero 1629: 3r).

Transcribo tan largo fragmento por varios motivos: en primer lugar, el salmantino recicla de nuevo aquí la alegoría sobre el panal y las abejas a la que ya he aludido como uno de los estilemas de Benito (o de Jacinto) Quintero ${ }^{34}$, pero este pasaje también confirma, en apenas veinte líneas, su tendencia a mezclar las citas veterotestamentarias con otras espigadas en el platonismo. El doctor nos regala una retórica citante, pero en la que el exemplum latino es amplificado por una glosa (otro exemplum, a fin de cuentas) contenido en las Escrituras. Es como si la categoría de Séneca como retórico necesitara de una amplificatio bíblica para probarse (la anécdota sobre Sansón y el león). Se trata de un recurso documentado más de una vez en el Templo: la cita que explana otra previa, las más de las veces un cuento, una fábula o una anécdota interpolada en la teoría. Ahora bien, no caigamos en el error de pensar que

34. Reaparece - a partir de Quintiliano (lib. I, cap. X de la Institutio) - en el punto segundo del primer discurso: «necesidad tiene de saber todo aquello para que, al modo que la abeja avisada y diligente saca de la golosina de diversas flores, que templa con su sagacidad el panal dulce, así el elocuente, picado acertadamente, saque el panal artificioso de la oración entendida y suave» (Quintero 1629: 8r). A veces, incluso embellece el lugar común, amplificándolo, con una serie de imágenes florales que se dirían aprendidas en fray Luis de Granada: «ha menester la abeja el conocimiento de tan varias flores, y saber del romero saltar a picar en el tomillo, en la retama descolorida y en la mosqueta alegre» (Quintero 1629: 8r-8v). 
esto es un hallazgo de Quintero, pues menudea en otras retóricas barrocas, comenzando por la de su partidario y amigo Juan de Robles, quien compuso El culto sevillano de acuerdo con esa técnica, o el propio Valentín de Céspedes, que incluyó en su manuscrito de Trece por docena «un amplísimo corpus de [...] cuentecillos jocosos [con los que] salpimentó todavía más su respuesta a Ormaza» (Cerdán / Laplana 1998: 66) ${ }^{35}$.

Como muestra algo bizarra, no hay duda, de esta tendencia, el panal en la boca del león aniquilado por Sansón es la clave de un exemplum que se orienta tanto a la probatio -validar lo dicho por Séneca- como a la amplificatio. Y no será ocioso recordar que el esquema de la argumentatio asumido por las artes de la predicación evangélica, que hicieron confluir las tesis clásicas y cristianas en torno a una narración ejemplar, es un proceso que «culminaría con el profundo estudio de la misma emprendido por fray Luis de Granada en su Rhetorica Ecclesiastica» (Aragües Díaz 1999: 209). Y otro detalle: ese «sabido suceso de Sansón» del que se beneficia Quintero aparece justo detrás de un pasaje de Séneca que, a todas luces, bastaba por sí solo para sugerir la idea de que "la elocuencia descaecía en las iglesias». Luego ese segundo episodio sobre un lance de la vida del forzudo filisteo cumple aquí la misión de exornar el discurso, mucho más que la de probar lo ya probado, en consonancia con esa mudanza retórica que a finales del Quinientos equilibró lo utile con lo dulce.

La defensa de la lengua del Siglo de Oro es lo más notable del primer discurso del Templo: «importa que caigan las palabras usadas y lenguaje común, sucediendo -como en el campo de la hermosura- otras hojas, otro estilo, otra elocuencia y otras voces para el uso común» (Quintero 1629: 5r). Un dictado que no admite medias tintas, pero que se vuelve más conceptuoso al descubrir que a esa máxima tan rotunda le sigue otra imagen que participa de la arquitectura y también de la épica: «aun los hechos gloriosos de los héroes mueren a las memorias, [...] los edificios se acaban y padecen ruina y de Troya dice la otra Penélope: Iam seges est, ubi Troia fuit» (Quintero 1629: 5r). Se trata de una cita del primer capítulo (v. 53) de las Heroidas de Ovidio; y de acuerdo con el silogismo de Quintero, si la lengua es un edificio, el poeta habrá de identificarse con un arquitecto, con un héroe y hasta con un jurista, pues otro lugar de Tertuliano (Apologeticum adversus gentes) le permite al salmantino añadir otra alegoría: las lenguas se sancionan, aplican y derogan como las leyes.

35. Aragüés Aldaz (1999: 127 y 148-149), que examinó la presencia de exempla (y de las teorías al respecto) en varias retóricas barrocas (Vieyra, Arriaga, Mendoza, Mesía de Tovar, Palomeque, Escardó, Murcia de la Llana, Suárez, Bravo...), ha iluminado también cómo las artes praedicandi de la Alta Edad Media comenzaron a desplazar ya «el interés del exemplum desde el terreno de la probatio al de la amplificatio, en concordancia con el progresivo distanciamiento de las teorías del sermón temático de sus precedentes clásicos. [...] Carlos Borromeo, impulsor en la diócesis milanesa de esa conciliación entre retórica ciceroniana y oratoria sagrada, manifestaba su oposición al uso de facecias (facetiae ridiculeve dicta) en el sermón, pero indicaba al tiempo lo apropiado del empleo de los exempla sanctorum, siempre que estos, como los miracula o las historiae, fueran confirmados por la autoridad de los Padres». Es lo que hace Quintero en el Templo, pues salvo alguna excepción relativa al gongorismo, sus ejemplos no acostumbran a ser chistosos. 
De ahí que no extrañe que Quintero (1629: 6r), tras acogerse a la autoridad de un adagio de Firmiano -o sea, Lactancio-, que, como vimos, ya había aprovechado Carrillo («Sapientiam sibi adimunt, qui sine ullo iuditio inventa maiorum probant»), y otra vez a la de Tácito («siempre andamos a pleito con este Proteo de la elocuencia, que tantas caras tiene»), desgrane un sucinto canon de escritores áureos:

Léanse los libros antiguos de Castilla: veremos cuán rudos están en su lenguaje y cómo Juan de Mena y Garcilaso le purificaron con nuevos aseos, y después Figueroa y fray Luis de Granada, hasta llegar a este escalón (no me atrevo a decir 'descanso', porque temo ha de subir más) en que hoy vivimos (Quintero 1629: 6r).

Valdrá la pena arrojar luz sobre los nombres de este párrafo. Quintero parece conforme con las propuestas del muy ciceroniano Palmireno, quien entró de lleno en el debate sobre la vigencia del Arpinate en pleno siglo XVI con su diálogo De vera et facili imitatione Ciceronis $(1560)^{36}$. En él dejó escrito que «si el Imperio se conservara, hubiéramos de seguir al pueblo romano y no a los libros, como en la lengua castellana no seguimos los libros de don Antonio de Guevara sino lo que cada día inventan en Toledo» (Palmireno 1573: 105). Pero no termina aquí la cosa. Quintero hace que comparezcan también Mena y Garcilaso, a los que Sebold (2001) catalogó como los «amos» de nuestros poetas ilustrados; al objeto de sugerir que la oposición entre el garcilasismo y el gongorismo no era tanto un fenómeno de reemplazo de una escuela por la otra, sino, más bien, de continuidad y progreso, como había predicado -lo hemos visto- Quintero tres siglos antes ${ }^{37}$.

No obstante, el nombre de Mena había disfrutado ya de cierto peso en los numerosos pleitos sobre el ciceronianismo. Así, Luján Atienza aclara cómo «la mención de Guevara [por parte de Palmireno] es ilustrativa al respecto y diría que en las antípodas de Quintero, pues representa la tendencia literaria, junto con Mena en poesía, a hacer del vernáculo un remedo del latín, vicio opuesto a aquel en que solían caer los estudiantes. De Mena llega a decir el aragonés: "porque si a un italiano para enseñarle a hablar la lengua espańola, le leyésemos Juan de Mena, nunca sabría hablar, y si hablaba, sería bárbaro" " ${ }^{38}$. Ahora bien, Palmireno presumía de ciceroniano en extremo, mientras que para Quintero el culto autor del Laberinto de Fortuna y el divino Francisco de

36. Luján Atienza ofrece bibliografía al respecto en el artículo incluido en este monográfico.

37. Y también Manuel Ponce en su Silva a las «Soledades» de don Luis de Góngora: «no será culpable nuestro autor de haber usado en su idioma tal vez de los casos y gramática de la latinidad imitando los que en ella escribieron con los términos de la griega. Y menos debe serlo introducir en su lengua voces latinas y toscanas con tanta moderación, pues el docto Juan de Mesa... y el ingenioso Garcilaso, en muchas partes de sus escritos usaron también voces latinas, toscanas y nuevas». Véase Azaustre Galiana (2015) en este mismo volumen.

38. Algo parecido escribiría después Jáuregui en su Discurso poético (1624): «Ejecutadas vemos en [...] Mena, poeta en su modo célebre, prodigiosas resoluciones que, no sabiendo contenerse, las emprendió y puso en obra con infelicidad notable. Dilata al fin su derecho a las más remotas licencias; destruye los periodos y oraciones por modos exquisitos y oblicuos; usa infinitas palabras latinas, griegas y compuestas» (Jáuregui 1978: 110). 
Figueroa, madrigalista que llegó a dominar la lengua toscana como si fuera la suya, habían puesto los cimientos de ese Templo de la elocuencia castellana que un siglo más tarde se adornó con la corona del gongorismo.

Y tampoco debe caer en saco roto, a propósito del ennoblecimiento (latinizante) del castellano, que el salmantino utiliza un sustantivo ("policía») que también figura en El culto sevillano (1992: 131) y significa lo mismo en español que en italiano: "limpieza, decoro, fineza, claridad..."; atributos, todos ellos, que desfilan por las polémicas pro y anticeronianas y que Bembo había perfilado en sus Prose, al igual que Valdés en su Diálogo de la lengua:

Vivamos con la pureza antigua y hablemos con la policía nueva; que de esa suerte (como abejas diligentes en el panal de Sansón juntaremos a las costumbres de cera blandas, puras, inocentes, la miel de la elocuencia usada (Quintero 1629: 6r).

Difícil encontrar una explicación mejor que esta del motivo de la imitación compuesta. Quintero recupera ahora su exemplum del panal de miel de Sansón para discurrir sobre un tema que había merecido -y continuaría mereciendoríos de tinta. Entre los más claros, sin duda, los de Lázaro Carreter (1979: 94-97) en su comentario de la Oda a Juan de Grial de fray Luis de León. Partiendo precisamente de la imagen aristofanesca de la abeja que, libando en múltiples flores, elabora su miel, repetida con insistencia por Lucrecio, en versos que luego recordaría Poliziano, Horacio (Odas, IV-2, vv. 27-32) y, claro, la epístola 84 de Séneca: «Apes, ut aiunt, debemus imitari», nos explica cómo este último llegó a formular incluso un método: «conviene coleccionar cuanto resulte atractivo en las lecturas, y tratar de dar luego a lo recogido un único sabor» (Lázaro Carreter 1979: 94-95).

Imagen repetida hasta la saciedad, no se olvide tampoco que asume un papel capital en el debate sobre el ciceronianismo, que llegó hasta las primeras décadas del Seiscientos. Por la sola razón de que aunque Petrarca y Poliziano copiaron esa metáfora apícola y se adhirieron a la postura de Séneca, no todos los rétores la admitieron sin encabritarse. Hay que recordar que la discusión se reanudó desde principios del siglo XVI, a raíz del Ciceronianus de Erasmo, fiel a Séneca, y de la disputa que mantuvieron entre 1512 y 1513 Gian Francesco Pico, sobrino del polígrafo holandés, y el citado Bembo, quien opuso que esa lectura de la imitatio medía muy inapropiadamente a todos los escritores antiguos con el mismo rasero, de manera que se atacaba el orden de su férrea jerarquía.

Sin embargo, no atropello a la razón al decir que se trata de un reparo propio de Perogrullo, porque cualquier poeta, y diría que todos los retóricos que en el mundo han sido, saben que la preferencia por unos maestros u otros como falsilla a la hora de escribir versos implica necesariamente la creación de un canon personal, subjetivo y por ello controvertido. Si en el Renacimiento los ánimos se enzarzaron en dar respuesta a la pregunta de qué autores había que imitar para ser un buen latinista, lo que propone Quintero en el Templo es averiguar el crédito que hay que dar a los poetas (Góngora, Villamediana) y 
predicadores cultos (Paravicino), los mismos que elevaron el vulgar a unos niveles que emulaban el de la lengua de los clásicos.

Según Luján Atienza (2015), «al hombre del Renacimiento se le plantea un doble problema: por una parte recibe del Medievo un latín corrompido que debe devolver a su pureza clásica y, por otra, la pujanza, extensión y dignificación de las lenguas vernáculas hace que estas ocupen parcelas que habían sido hasta ahora exclusivas del latín». Pues bien, a los poetas y oradores del Barroco se les plantea, por el contrario, la posibilidad no solo de ocupar espacios que habían sido coto vedado del latín, sino de guardar ese mismo latín bajo siete llaves, en los sutiles cofres romanceados de las Soledades y los sermones del Predicador Real de Felipe III.

De hecho, Quintero vislumbraba, porque lo había leído, otro apuro de fondo: desde mediados del Renacimiento, los poetas y los rétores afrontaron el desafío de que, al dejar de usarse -o usarse menos- en España el latín como lengua de cultura, los interesados en escribir en latín, o bien en latinizar su elocutio, caso de Góngora, debían mirarse en aquellos autores que mejor lo habían cultivado, que para oradores como Palmireno se cifraban en el nombre de Cicerón. Eso dio lugar a una serie de corrientes de sumisión, pero también de indisciplina -es difícil catalogar a don Luis como «ciceroniano»-, que redundó en el progresivo diseńo de una nueva elocuencia, tan deudora de los antiguos (Cicerón, Quintiliano) como de los pasos de gigante que habían dado las lenguas nacionales desde el adiós de la Edad Media. Por eso el párrafo en el que Quintero agrupa a Mena, Garcilaso, Figueroa y fray Luis de Granada se sitúa -por lo que atañe al romance- en la encrucijada entre los antiguos y los modernos; en el fiel de una balanza donde se contrapesan la latinización y la naturalidad, Mena y el Garcilaso más culto, con un horizonte a ras de Góngora -muerto solo dos años antes de la publicación del Templo- y todos los que lo siguieron.

\section{Propiedad y cordura del neologismo}

En el punto segundo de su primer discurso, Quintero desarrolla las cuatro columnas de la elocuencia, comenzando por la propiedad, y explica los vicios y las virtudes de las oraciones y las voces. El primer deber «es [conocer la] significación [de estas últimas], su fuerza y el alma de lo que en su primera acepción tuvieron, cómo se hacen lugar en la oración, con quién se juntan bien y a qué cosas se aplican» (Quintero 1629: 7r). Es evidente que al salmantino le preocupan las etimologías («su significación y el primer oficio que tuvieron») y que acusa de nuevo su ciceronianismo por lo que respecta a las leyes de relación entre las palabras dentro de la frase. Pero para fijar la «gramática de los nombres» se antoja básica la "erudición de artes, ciencias y ocupaciones varias» (Quintero 1629: 7r), sin las cuales no se podrá adornar el discurso. Así lo había adelantado ya Salcedo de Aguirre (1594: 178-179) en su Pliego de cartas en que hay doce epistolas escritas a personas de diferentes estados y oficios: 
No debe carecer el evangélico predicador de letras humanas, antes debe estar muy enriquecido de ellas, mayormente de la Filosofía natural, que enseña muchas propiedades y secretos naturales para confirmación de lo que se predica: [...] animales, árboles, yerbas, piedras y otras cosas semejantes. [...] La historia hace muy caudaloso al predicador [y] la poesía y [...] algunas sentencias de humanidad [...]. Será asimismo de mucha utilidad en ocasiones que lo pida traer un jeroglífico, emblema o empresa y aun alguna fábula de Isopo o de otro autor antiguo.

Como hiciera en el punto anterior, Quintero introduce un exemplum del Antiguo Testamento -recordemos el de Sansón y el panal en la boca del leóna modo de proemio; índice, sin duda, de cohesión argumentativa y de una meditada dispositio, aun cuando esta sea una parte de la retórica que parece traerle sin cuidado ${ }^{39}$. Para justificar esa «varia erudición» a la hora de construir su discurso, se basa en los versículos del Éxodo (5, 1-23), glosados por Filón de Alejandría, en los que Moisés, a quien Dios concedió el don de la sabiduría, pero no el de la elocuencia, y su hermano Aarón, que nunca decía esta boca es mía sin que se lo ordenase el profeta, se presentan ante el faraón. He aquí una fuente poco habitual (Filón) en las retóricas del Siglo de Oro, pues los dos libros de De vita Moysis no gozaron de renombre ni entre los hebreos, ni tampoco entre los griegos, si bien fue recibida con júbilo por los primeros cristianos, que aplaudieron su estilo un punto rebuscado y alegórico. Por otro lado, la cita sí que resulta natural en un pasaje sobre las etimologías, ya que este fue uno de los asuntos por los que más se interesó Filón, influido por las teorías de Pitágoras. A su juicio, Moisés inventó los nombres, que son revelaciones expresivas de las cosas, de manera que todos los inapropiados no hay que atribuirlos al profeta ${ }^{40}$.

Quintero (1629: 9r) no tarda en diferenciar entre las «voces propias usadas», las "voces propias desusadas" y las "voces de nuevo introducidas", ya sea "por derivación", ya "por necesidad y pobreza de la misma lengua»" ${ }^{41}$. El lenguaje

39. Lo confirman dos pequeñas citas en las que informa de su concienzudo trabajo, las dos a partir de Tácito: 1) «Enséńenos Tácito estos desprecios de la afectación y lo que debemos seguir con unas palabras que, por ser tales, no me correré de ponellas aquí, esperando repetillas en el segundo discurso» (Quintero 1629: 19v); y 2) «Aquí venía bien lo de Tácito [...] que cité en el punto tres del primer discurso» (Quintero 1629: 43v).

40. Quintero volverá a apoyarse en Filón al discurrir sobre la claridad. Nótese que el requisito de la erudición no niega que pueda haber «bien hablados» sin ella. Para explicarlo, el salmantino se vale del tercero de sus exempla, sacado del Brutus (58, [210]), pues Cicerón, hablando de Curio, se refería a él como «hombre de lenguaje puro, propio, claro y levantado, pero sin el tesoro de las letras» (Quintero 1629: 8v).

41. Su defensa del «neologismo por derivación» coincide con la de Díaz de Rivas en los Discursos apologéticos (c. 1624): «Y no es tan excesivo nuestro poeta [Góngora] en derivar voces latinas como algunos piensan, que condenan en él no la derivación, sino la exquisita afectación, pues en la Primera Soledad solas dedujo estas nueve voces: semicapro, mentido, pululante, arrogarse, delicioso, scisura, triplicado, bipartida» (Díaz de Rivas 1960: 44). Por otro lado, Robles (1992: 132) objetaba en El culto sevillano que «algunos pecan más disimuladamente, porque no traen en sus razonamientos vocablos latinos, sino nuevos, inventados por metáfora de los mismos nuestros, con que, destruyendo la pureza y propiedad, nos hacen notabilísimo dańo sin sentirse». Y también: «el inventar vocablos se ha de mirar si se inventan por necesidad o por aumento y 
preferible, haciéndose eco de Quintiliano (Institutio oratoria, lib. I, cap. 5 [5758]), es el que se amolda a lo que se conoce como teoría del sustrato -la lengua invasora adopta los usos de la invadida- y también a la del superestrato -la lengua invasora desplaza a la de los vencidos- (Jungemann 1956), porque el doctor admite que los romanos habían tomado muchas voces del griego, y viceversa, sin desdeñar la humorada de que el latín heredó la voz "gordo» del «español rudo», o sea, el previo a la romanización (Quintero 1629: 9v) ${ }^{42}$.

Respecto a las voces propias desusadas, el vicio que más le incomoda de los oradores de su siglo es el abuso de los arcaísmos para dar gravedad a la frase. Recicla de nuevo en su exposición la alegoría arquitectónica («Notable engaño [...] hacer que parezca bien en un edificio vistoso, nuevo y bien labrado unas ventanas que por viejas estuvieron hechas desprecio del pie entendido mucho tiempo», Quintero 1629: 10r), seguida de las reticencias de César y Tácito (Dialogus de oratoribus, cap. XXII [5]) a la exhumación de "palabras que borró el uso y de podridas güelen mal y están tomadas de orín. [...] Verdad es que una u otra vez tienen peso y gravedad en la oración; pero usar a cada paso el en vez, a fuer, empacharse, asaz, tamaño y otras de esta suerte es profanar la lengua sin ocasión» (Quintero 1629: 10r). Sin embargo, aunque no lo explicite, bajo ese parrafito late un eco de Quintiliano (Institutio oratoria, 8, 3, 24-25) cuando advertía que "las palabras olii, quianam, moerus, pone y porricerent van como perfumando su lenguaje [el de Virgilio] y le dan a su arte aquella inimitable dignidad de lo arcaico. [...] Pero este matiz de sabor antiguo ha de emplearse con mesura y no hay que sacarlo desde los más remotos escondrijos del pasado».

También a Séneca (epístola 114) le parecía una «enfermedad del alma este desagrado de las voces usadas» (Quintero 1629: 10r), metáfora médica que el doctor repite insistentemente a lo largo de este segundo punto y que, como vimos en el primero, con el que el exemplum ( $3^{\circ}$ del Templo) que sigue funda un paralelismo, remata con una anécdota de las Escrituras (Jn, 11, 35); eso sí, filtrada a través del tamiz de Tácito (cap. XXII [5]): «Cristo, [...] al resucitar al Lázaro, lloró, para dar a entender que murió en su uso, que ya la tiene el polvo y la losa en su jurisdicción y güele mal» (Quintero 1629: 10v).

El segundo vicio -con Horacio (Ars poetica, vv. 50-51) como brújula, cuya autoridad se agiganta en este epígrafe- es la introducción de neologismos gratuitos, disociando por dos veces los conceptos de «necesidad» y "gusto». Es más, basándose en Quintiliano, el salmantino indica que las palabras nuevas, ora traídas de las lenguas vecinas, ora derivadas de la propia, se pueden patrimonializar allí donde «con cordura y pocas veces [...] lo pide la necesidad,

lustre de nuestra lengua, porque se ha de tener diferente consideración en lo primero que en lo segundo" (Robles 1992: 144).

42. Recuérdese que Jáuregui trata el tema con cierta extensión en su Discurso poético (1978: 71-77) y que, todavía dentro de la polémica, Díaz de Rivas (1960: 39) justifica los neologismos de Góngora basándose en la autoridad del lingüista, y amigo del poeta, Bernardo de Aldrete: «[Don Luis] enriqueció la nuestra [lengua] y la adornó del atavío y galas extranjeras, descubriendo sus espaciosos y amenos campos, no hollados antes. Lo cual deseaba mucho nuestro Bernardo de Aldrete». 
no el gusto y afectación a la novedad» (Quintero 1629: 11r) ${ }^{43}$. Buen momento, pues, para aclararlo mejor, dando entrada a la primera cita que publica su aprecio por Góngora y el conde de Villamediana, a los que afea sin embargo la creación de neologismos cada vez más bizarros:

¿Qué razón hay para usar albor y candor, habiendo blancura en nuestro idioma? ¿Precipicio, habiendo despeñadero? ¿Armento y antro, habiendo cueva y ganado, tan puro y tan sonoro para el verso y prosa? Voces que aun el latino las ignora; vicio que me admira en ingenios tan raros y tan dignos de bronces y estimación perpetua como el conde de Villamediana y don Luis de Góngora (Quintero 1629: $11 \mathrm{r}-11 \mathrm{v})^{44}$.

En virtud de este párrafo, no suenan demasiado lejos los ecos de este otro de la Carta (1613) de Pedro de Valencia, tras su privilegiada lectura del Polifemo y las Soledades:

También, siguiendo esta novedad, usa de vocablos peregrinos italianos y otros del todo latinos, que los antiguos llamaban glosas, lenguas, y ahora llamamos así a las interpretaciones de los tales y de todo lo oscuro. Estos conviene moderar y usar pocas veces (Pérez Sánchez 1995: 76).

Acaso Quintero piense a menudo, como después Hebrera y Esmir, en el «Góngora menos gongorino, en el filtrado por Gracián» (Baldissera 2015); lo que sí sé es que para su condena de los neologismos aprovecha materiales del libro 8 (cap. 3) de la Institutio de Quintiliano («los romanos sintieron mal de esta licencia de introducir voces nuevas los griegos», Quintero 1629: 11v) y un exemplum (el $\left.4^{\circ}\right)$, que toma prestado a Suetonio, acerca de cómo el emperador Claudio desterró a un caballero griego de Roma porque no dominaba el latín. No hay duda, pues, de que en el crisol de citas en que acaba convirtiéndose este bloque, el salmantino se decanta por la moderación, ya que Salustio fue «inventor de algunas voces y frasis que ponía una sola vez u otra en la oración» (Quintero 1629: 12v). Es probable, no obstante, que al lector menos versado en la polémica gongorina le pase inadvertido que esta última cita figuraba ya en el Discurso poético de Jáuregui (1978: 88-89), fuente de la que creo que Quintero bebió más de una vez:

basta haberse entendido cuán ofensivas sean las locuciones peregrinas si con frecuencia se reiteran e inculcan, como vemos hoy por extremo en los afectados modernos. [...] Juzgue primero Séneca si son vicios. Así llama a las lociones audaces

43. A finales del siglo XVII, Fuster (1681:3) lo expresa con términos similares en su Brevísima método de componer sermones evangélicos que escribió a un amigo suyo, Valencia, Francisco Mestre, 1681 , lo que da fe de la moda del gongorismo a lo largo de una centuria: «Palabras obscuras, o por derivación, o por la novedad, habiéndolas ordinarias, proprias y castizas, se deben excusar, pues no se pretende ostentar lenguaje en el púlpito, sí persuadir el documento virtuoso, facilitando inteligencia».

44. Quintero se pronuncia aquí con más originalidad que otros teóricos, pues, como observa Baldissera, en el Jardín de la elocuencia (1677) de Hebrera y Esmir, que también acentuó la elocutio ( $4^{\circ}$ libro) sobre las otras partes de la retórica, las citas textuales del franciscano incluyen a Góngora, pero no a sus epígonos. 
de Salustio, que imitaba Arruncio, aunque eran lustrosas y elegantes como lo muestran en el lugar que antes alegamos.

Con más finura lo había sugerido también el abad de Rute en su Parecer (1614), quien, más allá de la riqueza de cultismos y neologismos, aconsejaba cierta prudencia al emplearlos:

Lo mismo deseo haga en el uso de palabras peregrinas, digo derivadas de latín y toscano; y no tanto en la muchedumbre de ellas, pues todas son muy buenas, y a la verdad esto es enriquecer nuestra lengua y muy conforme a los preceptos del arte; [...] pero en el frecuentarlas y repetirlas muy a menudo, pues como a forasteras se ha de ir poco a poco, y con recato, dándoles entrada y lugar señalado (Roses Lozano 1994: 154).

\section{Y también el anónimo antequerano:}

Puede muy bien el poeta, como notó Herrera, usar en todo tiempo, con prudente libertad, de vocablos nuevos, y le ofende y le hace grandísima injuria quien le priva de la facultad de ordenar con ellos su poema porque, como dice Cicerón, los poetas hablan en otra lengua y no son las mismas cosas que trata el poeta las que el orador (Osuna Cabezas 2009: 99.)

Tampoco Jáuregui cambia el tercio, luciendo, eso sí, su afilada malicia en el Antídoto contra la pestilente poesía de las Soledades (1616):

Aunque es verdad que al poeta heroico es lícito usar vocablos nuevos y extranjeros, según el Arte de Horacio, el de Aristóteles y otros, juntamente es precepto suyo que en esto haya gran tiento y moderación (Jáuregui 2002: 36).

No sabemos si Quintero tuvo noticia de este opúsculo o de otros textos de la polémica -no cita a ninguno de los participantes, aunque comparte no pocas ideas de Díaz de Rivas, del anónimo y hasta alguna cita exacta del Discurso poético de Jáuregui, al margen de que le reprocha a Góngora en el Templo los mismos defectos que el sevillano: neologismos, trasposiciones e hipérbatos-. Lo seguro es que el uno y los otros leyeron las mismas fuentes para atacar el gongorismo y, lo que más importa, para legitimarlo: Séneca, Marcial, Virgilio, Catulo, Mena... Azaustre Galiana lo explica con detalle a la luz de las ideas retóricas de Manuel Ponce, uno de los primeros comentaristas del cordobés, cuya Silva a las Soledades, perdida durante décadas, rescata en este monográfico y editará a no tardar mucho:

La Sylva a las Soledades y la Epistola al conde de Villamediana sitúan a Manuel Ponce como defensor de Góngora y el estilo culto, dentro de la polémica que protagonizó el panorama literario de las primeras décadas del xvir. [...] Dos notas donde Ponce se demora algo más en consideraciones retóricas afectan a las que, en general, podríamos englobar bajo el rótulo de verba peregrina, es decir, voces nuevas y de otra lengua. Es un aspecto que preocupó mucho a Ponce, quien le volverá a dedicar una amplia sección de su Discurso en defensa de la oscuridad, y que centrará, en torno a 1617, su Epistola a Villamediana.

Por otra parte, la saeta que Quintero había disparado contra Góngora, las más de las veces apunta a la diana de sus epígonos, tal como se ve no solo en 
las retóricas de la época sino en la novela (Bonilla Cerezo 2010) y el teatro (Samonà 1990). Lo mismo se infiere del quinto exemplum de su retórica, esta vez una anécdota chistosa: «en Salamanca conocí yo un caballero estudiante que, desvanecido en esta imitación de Góngora, llamaba a las narices turbante olfático, a las pantorrillas globos pensiles, al sombrero chapitel urbánico» (Quintero 1629: $12 \mathrm{v}-13 \mathrm{r})^{45}$.

Bien es verdad que la facecia del hiperculto con el que se topó nuestro rétor puede ser tan verídica como literaria, por la sencilla razón de que desde mediados del siglo XVII corrían de boca en boca una serie de cuentecillos en los que se ponía en solfa la revolución poética del cordobés. Así, por ejemplo, una colección de Arguijo en la que alaba (o se ceba) con Garcilaso, Quevedo, Céspedes y el mismo Góngora (Ruiz Pérez 1984); o bien la novelita El culto graduado (1625), de Castillo Solórzano, en la que Alcaraz abandona su villa de Casarrubios rumbo a Salamanca, donde tendrá que superar el examen de un Gymnasium Cultorum (Bonilla Cerezo 2010); sin olvidar, por supuesto, la oleada de vejámenes contra los cultos que se gestaron en las aulas del Alma Mater Salmanticensis. Rodríguez de la Flor (1999: 40 y 54) ha razonado cómo estos «constructores de telarañas» tienen como característica

el desatender a la realidad empírica; el olvidarse del fenómeno e intentar construir una imposible "ciencia de noumeno". Caminan ciertamente hacia lo oscuro, por lo oscuro; obscuro per obscurius. [...] [En Salamanca], los príncipes del pensamiento y de la intelectualidad española comienzan a ser comprendidos ya claramente como hombres equivocados, perdidos en el laberinto de palabras sutiles y vanas. [...] El acto fundacional de la carrera del hombre de letras, el recibimiento del grado, se despeña con el tiempo en una degradación inaudita, de la que dará cuenta un nuevo Norberto Caino, cuando evidencia el latín risible que se utiliza en tales actos, el amontonamiento de erudición bárbara y el ridículo ritual que sigue el acto, todo ello ya a fines del XVIII.

La apuesta de Quintero por las «voces comunes», a la zaga de Cicerón y del capítulo $2^{\circ}$ del libro 8 de la Institutio de Quintiliano, a los que cita y recita sin cesar, hasta el punto de pedir excusas, porque uno de los defectos de esta retórica es precisamente su machaconería («No se enfade el lector si le repitiere muchas veces, pues le debemos afición por nuestro y crédito por entendido en la elocuencia», Quintero 1629: 14v), pone el colofón a este segundo punto ${ }^{46}$. Había escrito el rétor de Calahorra: «En el intento de evitar esta falta suelen caer en no pequeńo error algunos, que tienen mucho miedo a todo lo que pertenece al lenguaje corriente, aunque lo exija la necesidad del asunto tratado» (Quintiliano, 8, 2, 2-3).

En consecuencia, su empleo en el lugar adecuado de la oración, con «aliño» e «ingenio», apuntan rápidamente al conceptismo. Condenando los arcaísmos, Quintero salvaguarda los neologismos, porque -en la línea de las Advertencias

45. Otro chiste parecido cierra el punto cuarto del primer discurso (Quintero 1629: 28r): Cicerón (Brutus, 74 [260]) se había burlado de Sisena, un orador poco entendido que pecaba de culto.

46. Ya se había detenido en ellas Jáuregui (1978: 77) en su Discurso poético. 
para la inteligencia de las Soledades de don Luis de Góngora (c. 1614), de Almansa y Mendoza- el paso del tiempo es razonamiento decisivo para aceptar los vocablos nuevos: «los nuevos tiempos exigen nuevas palabras, y la costumbre se encarga de legitimarlas, así sucedió con las de Garcilaso y así sucederá con las de don Luis» (Roses Lozano 1994: 155). Pero dicha introducción, como es lógico, no puede hacerse a tontas y a locas. En clave de batalla gongorina, neologismos y cultismos sí, como defiende Almansa, pero no en demasía, tal como piden Pedro de Valencia y el abad de Rute. Y neologismos que no dispongan de un equivalente en castellano.

Para no cansar demasiado, espigo solo algunos de los nombres de la polémica sobre las Soledades, los suficientes para demostrar mi tesis: Quintero es miembro de pleno derecho de la república de los rétores, pero también militó entre los apologetas y detractores de Góngora -tornadizo como era- de la segunda década del Seiscientos. Su conceptismo, en palabras de Martí (1972: 292), no devuelve tanto la imagen de un defensor teórico de ese movimiento cuanto de «una concepción muy dinámica del lenguaje, y es el autor que más se distingue en ese punto».

\section{Robusto y no afectado adorno}

Lo que distingue al Tempo de la elocuencia castellana de otras retóricas del siglo XVII es que a Quintero no le ha interesado la inventio, la dispositio, ni las sempiternas listas de figuras y tropos. Tan solo le preocupa la elocutio, o sea, el adorno, segunda columna de su libro y condimento innegociable de todo buen orador. Aprovechándose de una alegoría -tras las del templo y las leyes (puntos 1 y 2)- que identifica la lengua con el cuerpo humano, al hilo de lo dicho por Tácito en su Diálogo de oratoribus (cap. XXI [8]), expone que el estilo aliñado descansa sobre tres pilares: 1) «la buena elección de voces puras, sonoras, blandas y de muchas vocales» (Quintero 1629: 15v); 2) los adjetivos o epítetos (no así los «epítetos holgazanes»), que a su juicio son «la gala mayor de la lengua y en lo que consiste la mayor parte de su buen uso» (Quintero 1629: $15 \mathrm{v})$; y 3) las traslaciones.

Lo más atractivo tiene que ver -por su proyección gongorina- con el segundo de ellos. Según el doctor, «no es inferior en nada a estos acertados poetas [Virgilio] nuestro don Luis de Góngora, que en esta parte le debe, aun la mordacidad, veneraciones: al guarvín [sic] de las hijas del isleño llamarle, por azul, celoso alcaide de sus hebras de oro. Al carbunco, animal que tiene en la frente el lucimiento de su piedra, carro brillante de noctuno día (Quintero 1629: 15v).

El párrafo destaca porque Quintero cita de memoria, equivocándose, un verso de la Soledad segunda ("celoso alcaide de sus trenzas de oro», v. 451; Gongora 1994: 483), relativo a la redecilla de estambre que recogía los cabellos 
de la pescadora Éfire ${ }^{47}$; y más aún por un detalle que repercute sobre la crítica gongorina de nuestros días, ratificando que lo que podríamos llamar «tradición indirecta de las Soledades» dentro de la polémica, e incluso de la recepción de las silvas de don Luis a lo largo del Seiscientos, ayuda a dilucidar misterios («enigmas de la Esfinge» los llamaba Pellicer) que siguen dándonos más de un quebradero de cabeza. Me refiero a su definición del carbunco como animal en cuya frente brilla una piedra, protagonista de un pasaje de la Soledad primera que ha motivado que muchos filólogos, antiguos y modernos, se devanasen los sesos. Recordemos que, todavía en el arranque del poema, el peregrino «atento sigue aquella / (aun a pesar de las tibieblas bella, / aun a pesar de las estrellas clara) / piedra, indigna tïara / (si tradición apócrifa no miente) / de animal tenebroso cuya frente / carro es brillante de nocturno día: / tal, diligente, el paso / el joven apresura, / midiendo la espesura / con igual pie que el raso, / fijo -a despecho de la niebla fría- / en el carbunclo, Norte de su aguja, / o el Austro brame o la arboleda cruja» (1613, vv. 75-83) (Góngora 1994: 213-125).

Un reciente trabajo de Arellano (2014) explica las causas por las que se ha discutido tantísimo qué animal tenebroso («nocturno») era ese que lucía en la frente un carbunclo que centellea en la oscuridad: se ha dicho que era un lobo, un tigre, un dragón, un perro, una amada desdeñosa (i!), un ciervo, un lince... pero, en realidad, Góngora se refiere a un animal del que se hablaba por entonces, casi siempre en el contexto de las Indias, donde distintos escritores lo describen, y que se llama carbunco o carbunclo, como la piedra que se asegura que porta en la frente:

Según la mayoría de los textos áureos que enseguida glosaré, es un animal nocturno, cuadrúpedo, herbívoro, que tiene un carbunclo en la frente, el cual brilla en la oscuridad de la noche, y cuyo fulgor puede ocultar echando sobre él un sobrecejo o párpado que tapa o muestra la luz según le conviene. Cuando se ve perseguido o se asusta, cierra el párpado y desaparece en lo oscuro. A veces se le asocian rasgos que la tradición atribuye a los dragones y su piedra (la draconites), y en tiempos más modernos se descompone y recompone en características dispersas, formándose una tradición que vive -como es usual- en variantes, algunas ya muy alejadas de la formulación gongorina (Arellano 2014: 214-215).

Tras documentar que el comentarista que más se acerca a su lectura es el anónimo de la Defensa e ilustración de la Soledad primera, que hablaba ya del sobrecejo, pero sin dar el nombre de ninguna especie, Arellano sustenta su tesis en una cita (lib. 20, cap. 10) de la Historia General y Natural de las Indias de González de Oviedo, en unos versos del poema La Argentina de Martín del Barco Centenera, en otros de la Mosquea de Villaviciosa, en un poema de Francisco de Figueroa -al que, como sabemos, elogió nuestro Quintero-, en un párrafo de Céspedes y Meneses en la Varia fortuna del soldado Pindaro, y, gracias a una noticia que le dio Andrés Eichman, en la Historia del Santuario de Nuestra Señora de Copacabana (1621, lib. 1, cap. XIII) de fray Alonso Ramos

47. No es descartable, empero, que "trenzas», en lugar de "hebras», figurara en el manuscrito que manejaba Quintero. 
Gavilán, amén de en un largo rosario de autores latinoamericanos del siglo XX e incluso en blogs.

Si releemos el fragmento de las Soledades, lo primero que hay que señalar es que el problema quizá derive de un estorbo no solo semántico sino también sintáctico. Góngora no escribió que su peregrino iba «fijo en el carbunclo del carbunclo", porque sería esta una tautología muy burda, indigna de él, mucho más si consideramos que debió de pensar que el sustantivo ("carbunclo») daba pie a una metonimia (la piedra como símbolo de toda la fiera) y también a una bisemia, en tanto que el carbunclo era para don Luis la brillante piedra y el bizarrísimo cérvido hacia el que avanza el protagonista. Pero tampoco hay que descartar que el sintagma «de animal tenebroso cuya frente...» es matizado enseguida por una amplificatio que hace las veces de aposición clarificadora, a la que, sin darnos respiro, suma otra de carácter náutico («en el carbunclo, Norte de su aguja»). Nótese cómo los periodos oracionales de este fragmento vienen introducidos por dos epítetos acerca del caballero errante de las Soledades, un par de adjetivos que se dirían sinónimos: «atento sigue [...] aquella piedra de animal tenebroso" y "fijo [...] en el carbunclo». Luego Góngora hubo de pensar que sus lectores, simplemente por medio de la sintaxis, resolverían el silogismo sin mucha dificultad: 'animal tenebroso = carbunclo'.

No me he olvidado de las autoridades enumeradas por Arellano. Todo a su tiempo. Empero, en un capítulo que aspira a resolver el enigma de otra fiera gongorina -las que cazó Polifemo para lucir su elegante zamarra: «su piel manchada de colores ciento» (1612, IX, v. 68)-, Ponce Cárdenas (2010: 171239) explica, basándose en un buen número de fuentes latinas (Claudiano, Virgilio, Horacio, Ovidio, Estacio, Lucano) y hasta pictóricas, que don Luis no pensaba en un ciervo, ni tampoco en un tigre (como sugirieron Pellicer, Salcedo Coronel, Cuesta y, ya en el siglo XX, Vilanova), sino en un lince, uno de cuyos atributos en los textos, según una tradición paradoxográfica (Ovidio, Claudiano), se cifra en que «su orina, al ser expulsada y entrar en contacto con el aire, se solidifica para transformarse en una gema preciosa de potentes virtudes (el lincurio)» (Ponce Cárdenas 2010: 202).

Para reforzar su corolario, echa mano de un artículo de Piñero (2002) donde este demostraba -o eso creía él- que el complejo símil introducido por Góngora en el paisaje crepuscular de la Soledad I por el que correteaba el «animal tenebroso" solo cobra pleno sentido a la luz de las historias legendarias que circularon en torno al lince durante el siglo XVII. Resumiendo: Góngora llama «indigna» a la piedra que brilla en la cabeza del supuesto «lobo cerval» porque, como se había repetido desde las Metamorfosis de Ovidio y la Historia Natural de Plinio, el lincurio nace de la orina del más bello felino de la Península.

Todo perfecto, si no fuera porque no parece nada lógico que esa gema, excretada por el rarísimo animalito que gustemos, se trasladase -como por arte de magia- del suelo a la frente del lince. Así, me convence poco la glosa de Manuel Ponce en sus tempranos Comentarios a las Soledades del gran poeta Luis de Góngora (ms. 114 de la RAE, fol. 107v), de los que Ponce Cárdenas (2010: 230) se vale para justificar su tesis: «haber tenido esta vulgaridad su fundamento 
y principio en los ojos del lobo, los cuales en las tinieblas de la noche lucen y resplandecen tanto que parecen un hacha encendida a quien los mira de lejos». Magnífico, pero por mucho que brillen en la oscuridad, el erudito se olvidó de aclarar cómo ese tercer ojo pasó a adornar, a guisa de tiara, la frente del, por ahora, lince. No creo que los villanos que iban por el campo en pos de tesoros confundieran los dos destellos de la mirada del supuesto felino con solo una $(\mathrm{y}$ no con dos) piedras. Y tampoco que se pueda establecer -en este fragmentoesa absoluta identidad entre el carbunclo y el mucho más plebeyo -al menos en su origen- lincurio.

No cuento, en definitiva, con otros avales que el paralelismo sintáctico, las aposiciones, la metonimia y la dilogía ya citadas. Sin embargo, la frasecita de Quintero en su Templo de la elocuencia, el único texto más o menos lindero de la polémica en el que he dado con una noticia de este tenor, aclara bastante las cosas: «Al carbunco, animal que tiene en su frente el lucimiento de su piedra». Dónde lo leyera el salmantino -porque dudo mucho que llegara a ver ningunoes otro cantar, pero no lo es tanto que solo dos años después de la muerte de Góngora, cuando la controversia en torno a su obra atravesaba solo por una de sus primeras fases, interpretara sin aparente dificultad $-y$ sospecho que como él otros muchos- unos versos que, valga la ironía, han venido necesitando de la piedra filosofal o de la ciencia del más imaginativo de los biólogos ${ }^{48}$.

Cierro ya el paréntesis. Cuando Quintero repara en las traslaciones, o sea, en las metáforas, exige que se asemejen a las voces que sustituyen. Por eso, aunque no lo declare, queda claro que desaprobaba muchas licencias de los cultos, con don Luis al frente; porque si imágenes como "pisar miedos» $\mathrm{y}$ "llorar pasiones» le resultaban impropias, no es difícil deducir que tampoco serían de su agrado dos hermosas metáforas del Polifemo y las Soledades, construidas a partir de la relación de un verbo concreto («pisar») con un complemento directo más que abstracto: "pisando la dudosa luz del día» (Polifemo, 1612, VIII, 69-72) y «entre espinas crepúsculos pisando» (Soledades, 1613, v. 48).

El segundo vicio de las metáforas -tanto Séneca como Quintiliano la desaconsejaron, pues deviene en oscuridad- es la acumulación, puesto que convierte a los hablantes en "oradores de melcocha» y -lo repite varias vecesen «afeminados», «histriones» $\mathrm{y}$ «danzantes». Una decidida toma de partido a favor del «estilo común»-recuerdo que antes trató de las «voces comunes»- y en contra de la afectación, con ejemplos que van desde Enodio a Tácito y el Cantar de los Cantares (Quintero 1629: 19r-19v).

\section{Todo bien claro}

Quintero consideraba que entre las galas del lenguaje ninguna supera a la claridad, fruto de la propiedad de las palabras, el uso de la colocación fácil

48. Matizo por ello esta lección de Jammes (1994: 212): «Indigna tïara: la cabeza es indigna, no la tiara: hipálage sencilla, cuya génesis se discierne en las dos versiones anteriores de este verso». Según he explicado, la indigna sí es la tiara, obviamente; o sea, la piedra que corona la frente-como un tercer ojo- del carbunclo. 
y la brevedad de los periodos. Lo argumenta con un bello traslado de una cita de Filón («La claridad de la voz es la que saca el concepto de la noche de sus escuridades a la luz pública de su conocimiento», Quintero 1629: 22r); y añade: «En no siendo claro y fácil el lenguaje, por más que conserve su entereza de voces levantadas, es desaprovechado y holgazán», Quintero 1629: 23r). Luego será difícil ya que el doctor baje el pie del estribo de su "anticarrillismo", aunque en el Templo se dirija a los oradores, y no a los poetas, dos actividades creativas y hasta sociales más que diferentes en todos los siglos y un poco menos en el de Oro. Recordemos que Carrillo y Sotomayor había roto todas sus lanzas en pro de la docta oscuridad:

no pretendo yo, por cierto, ni nunca cupo en mi imaginación lugar a aprobar la oscuridad por buena, el mismo nombre lo dice, sus mismos efectos lo enseñan. [...] [Pero] no es bueno le ofenda la oscuridad del poeta siendo su saber o su entendimiento el oscuro" (Carrillo y Sotomayor 1992: 74 y 77).

La dicotomía queda rubricada cuando Quintero (1629: 25r) sentencia que "este lenguaje es ocioso y holgazán, pues aun el ingenio cuidadoso del oyente no le alcanza». Y poco después, ya sin ningún titubeo: «con más claridad nos descubre el docto hebreo Filón que nace de ignorancia esta oscuridad de lenguaje, como de erudición la claridad» (Quintero 1629: 25r). En el bando de la claridad militaban, entre los antiguos, Agustín, Juan Crisóstomo, Quintiliano y Séneca, que tachó la oscuridad de "embriaguez sin acuerdo» ${ }^{49}$, pero también hay que atender a un epigrama satírico, copiado de Marcial (lib. VI, epig. 41) (un «orador ronco que, no pudiendo echar la voz del cuerpo, por su achaque, se moría por orar porfiadamente, que este ni podía hablar por su mal, ni callar por su condición", Quintero 1629: 23r), como arma arrojadiza contra los "cultos de noche» $\mathrm{y}$ "bachilleres de estómago». He aquí, a mi entender, cómo el doctor vuelve a levantar acta de la esmerada dispositio de su discurso, pues el epigrama sirve como antítesis del exemplum-emblema del punto previo, en el que se recreaba en los hilos que salían de la boca de Hércules. Y no se pierda de vista tampoco, al final del libro, cómo Quintero, cristianizándola, le da una vuelta de tuerca a esa misma pictura para enarbolarla contra los cultos: «no son pescadores, discípulos y secuaces de Cristo, $[\ldots]$ sino arañas juguetonas que, con telas débiles, procuran divertir» (Quintero 1629: 46r) ${ }^{50}$.

El punto cuatro se abrocha con otra analogía: a las ya vistas entre el orador y el arquitecto, el orador y el legislador y el orador y el anatomista, sigue ahora

49. No supera el terreno de la coincidencia, pero convendrá al menos anotar que a Quintero (1629:) «este género de la elocuencia envuelta y dificultosa parecen más pasos de un hombre tomado del vino, que yerra y da traspies, sin que sepan hacia dónde camina, que de persona acertada y que tiene sentido». ¿Habría que leerlo como un malicioso ataque a la oscuridad de las Soledades, al gesto de desafío del cordobés con su nueva poesía e incluso al íncipit de las famosas silvas: «Pasos de un peregrino son errante / cuantos me dictó versos dulce Musa, / en soledad confusa, / perdidos unos, otros inspirados» (vv. 1-4? Lo señalo porque unos párrafos más abajo insiste en el tema: «Mas si se ignora la causa que se trata, el mismo lenguaje da pasos errados, valiéndose de voces oscuras por impropias y que no arman el concepto» (Quintero 1629: 25r).

50. Véase Herrero Salgado (1996: 424-436). 
una repetidísima desde el Arte poética de Horacio, a la que también se acoge Quintero: el poeta y el pintor, o sea, el tópico de ut pictura poesis. Del mismo modo que el pintor ha de ser claro, el poeta no debe oscurecer a sabiendas su discurso. La poesía clara y buena nunca cansa por su facilidad, mientras que la mala es la que apetece oscuridades. Vuelve sobre ello más tarde:

Es arte la poesía que consiste, como la pintura, en la imitación y así es hermana suya; e importa que no solo se valga para su uso de las voces y traslaciones comunes, sino que con nuevos colores entretenga y deleite; de donde nació que a la pintura la llamasen los cuerdos "poesía callada», y a la poesía, "pintura con voz» (Quintero 1629: 34r).

Bajo la especie del lugar común, vislumbramos alguna pista de valor en una retórica cuyo segundo tratado se reserva al uso de los predicadores. Es cierto que esa máxima de Simónides de Ceos (VI-V a. C.), luego matizada por Horacio en su Arte poética ${ }^{51}$, era ya un tópico en muchas de las preceptivas pictóricas y literarias de finales del siglo XVI. Pero la Sevilla barroca, «Minerva bética» por la que zascandileó nuestro Quintero, era una ciudad muy especial en este sentido. Por la sencilla razón de que había alumbrado un círculo de intelectuales (Mal Lara, Villegas de Marmolejo, Francisco Pacheco) entre los que no faltaba una curiosa figura: la del pittore letterato. Lleó Cañal (2012) ha profundizando en las obras de personajes como Pablo de Céspedes, Francisco de Medina, el citado Pacheco, en cuya academia se dio cita el núcleo duro de tan versátiles individuos (Calatayud, Jáuregui...). Y Portús (2012) y González García (2012) han anudado las conexiones entre el estilo, el decoro y el juicio crítico de los predicadores con trazas de pintores, o simplemente intesados por la pintura, que eran más que estrechos y con los que habría que comparar muchos de los artes concionandi del Seiscientos, sobre todo a partir de la importancia concedida a la descriptio - en la que Quintero solo repara para tolerarla en un Padre de la Iglesia como san Cipriano: «Y no es menos culpable gastar en descripciones poéticas y demasiadamente puntuales el tiempo, la saliva y el papel» (Quintero 1629: 41r) - en la Censura de la elocuencia de Ormaza, con su innovadora técnica de "pinturas» dentro de los sermones ${ }^{52}$. Y es que, según Lichtenstein (1989: 106), «telle est la définition paradoxale de l'éloquence: un art du discours qui se juge en un coup d'œil, une parole dont l'appréciation dépend uniquement du regard!».

Sabemos que el pintor católico, a imagen del orador sagrado, buscaba la persuasión, mas no con la palabra, sino con los medios cromáticos que tenía a su alcance. No sorprenderá por ello que muchos de aquellos pintores fueran también entonces "predicadores mudos" (Vargas Lugo 1995) ${ }^{53}$. El mismo González García (2012: 91-98), confirma -y esto refuerza la máxima del Arte poética de Horacio en el Templo de la elocuencia castellana- que los tratadistas de

51. Véanse Lee (1940) y García Berrio y Hernández Fernández (1988)

52. Es la línea que viene trazando Tanganelli (2011 y 2012).

53. Véase también Fumaroli (1995). 
la segunda mitad del Quinientos y los del Barroco, hasta 1630-1650, atribuirán al pintor sacro las mismas funciones del orador: enseñar, deleitar y conmover; destacando entre ellos la Retórica (1569) de Arias Montano, el Manual sobre ambas invenciones, la oratoria y la dialéctica, de Juan Costa y Beltrán (1570), el Modus concionandi (1576) de fray Diego de Estrella, los Avisos cerca algunas partes que ha de tener el predicador (1616), de Francisco de Rioja; y sobre todo El predicador de las gentes san Pablo (1638), de Juan Rodríguez de León.

Tampoco Quintero renuncia al dardo contra los exégetas de este tipo de vates («elegantes de máscara y rebozo») en un pasaje que haría las delicias del Carreira de «Defecto y exceso en la interpretación de Góngora» (1998: 47-73). Quintero (1629: 25v) advierte que «creció esta necia persuasión de tener lo que necesita de comento solo por elegante y culto, haciendo agrado a muchos entendello o interpretallo no como cosa que la decía el autor, sino como delgadeza que ellos inventaron sobre aquellas palabras».

La clave de la nueva poesía, tal como él la concibe y he venido sugiriendo desde el principio, radica en el «alma del concepto» y muy poco en la hojarasca de las transposiciones, los hipérbatos y según qué neologismos ${ }^{54}$. Proliferan a lo largo de esta retórica sintagmas como «voces escuras que no arman el concepto», «vistieron su concepto», «roba la atención y el gusto, sin permitirla al concepto», «exprima los conceptos» (casi un presagio de la Agudeza y arte de ingenio de Gracián) y otros de este jaez que el salmantino adoba con pulidas metáforas:

Sea, pues, [...] nuestra elocuencia siempre Clicie enamorada del Sol, para lo que hay que huir de las principales amenazas: 1) «frasis o traslaciones desusadas, ocultas y ignoradas con uso de colocaciones que no las admite la lengua; como la interposición de la castellana En angosta le hallaron callejuela, ni la dilatación de las cláusulas (Quintero 1629: 26r) $)^{55}$.

Es poco original, pero sí ilustrativa, su capacidad para distinguir, de acuerdo con la perspicuitas, que hay dos tipos de oscuridad, la que deriva de las res, mucho más permisible, y la de los verba, de modo que hay que interpretar el siguiente párrafo como una concesión a las tesis de Carrillo y Sotomayor, Jáuregui y Díaz de Rivas ${ }^{56}$, pero también como signo de su coherencia expositiva, pues en el

54. En el último tercio del siglo XVII, Hebrera Esmir (1677: 52) aún hace uso de sintagmas semejantes ( No ha de contentarse el orador con pulir el estilo, medir los periodos, esmaltar la gala y hermosear el artificio; ha de procurar igualmente de la sustancia, del nervio de la doctrina y de la alma de los conceptos») en su Jardín de la elocuencia.

55. Sus frases traslucen estas otras de Jáuregui (1978: 79) en su Discurso poético: «Hallaremos pues en los nuestros, no solo traslaciones tales, sino con aspereza doble, porque aun las mismas metáforas metaforizan».

56. «No es ni debe llamarse oscuridad en los versos el no dejarse entender de todos, y que a la poesía ilustre no pertenece tanto la claridad como la perspicuidad. Que se manifieste el sentido no tan inmediato y palpable, sino con ciertos resplandores no penetrables a vulgar vista: a esto llamo perspicuo y a lo otro claro» (Jáuregui 1978: 125). Según Díaz de Rivas (1960: 49), «hay, pues, dos especies de oscuridad en la Poesía: una nace de las historias, de los pensamientos delgados, del estilo sublime; otra, de la contextura anfibológica de las dicciones, y esta última es viciosa». 
segundo punto del primer discurso Quintero expuso que para llevar a término la "grámatica de los nombres» se precisa de la «erudición de artes, ciencias y ocupaciones varias». Ahora puntualiza además que "verdad es que hay cosas escuras de su naturaleza; o por las alusiones a historias, a fábulas o antigüedades; o por lo sutil y envuelto de sus materias; y en estas, el ser dificultosas no nace del estilo del autor, sino de la ignorancia del que las oye y del poco estudio del que las lee» (Quintero 1629: 27v) ${ }^{57}$.

\section{Elocuencia acomodada}

Uno de los mejores capítulos del Templo es aquel en el que Quintero (1629: 31r) evalúa la noción de decoro («la elocuencia debe acomodarse a la variedad de las materias", "es razón que las palabras convengan con la vida»), en sus dos vertientes, arriesgándose a veces en «formulaciones de tono quizá excesivamente anacrónico, por su fidelidad última a la letra horaciana» (García Berrio 1980: 217): la lingüística, que, simplificándolo mucho, consiste en atribuir al asunto un verbum que no le corresponde; y la relacionada con el público y, más todavía, con la diferencia entre los poetas y los oradores, que posee larga tradición. El primero de los asuntos es además uno de los focos de litigio en la batalla sobre las Soledades; de hecho las palabras del salmantino le vienen como anillo al dedo a otras muchas de los que se enzarzaron en tan acalorado debate: «ni a la corona y dosel majestuoso se ha de tratar con las voces que al sayal villano, ni el cortesano ladino se ha de introducir con las vulgares de un sayagués humilde» (Quintero 1629: 29r).

Y añade, apoyándose en Horacio (Arte poética, vv. 114-117 y 143-144): «importa que el repúblico hable como tal, el anciano grave, el mancebo lozano, la mujer blando, el villano humilde y el oficial templado" (Quintero 1629: $31 \mathrm{v})$. Ni que decir tiene que es justo lo que Góngora no hizo en las Soledades -el peregrino se topa en la primera silva con unos "conducidores de cabras» $(1613,62)$ liderados por un anciano que evoca tiempos bastante más gloriosos para él («cuando el que ves sayal fue limpio acero», 1613, v. 217), probable remedo de un cortesano «ladino", aunque sin duda "grave», por utilizar los adjetivos de Quintero, que he identificado junto a Tanganelli (2013: 41-45) con el duque de Béjar ${ }^{58}$. Lo mismo vale para el Polifemo, pues Quintero observa que «las voces altas ruidosas y levantadas no se aplican bien [a la descripción de un bodegón» (Quintero 1629: 33r), y bastaría con leer las octavas X-XI y XXIX de la Fábula del cíclope y la nereida para descubrir que Góngora estaba convencido de lo contrario ${ }^{59}$.

57. Véase Herrero Salgado (1996: 424-436), quien espiga ideas semejantes en el padre Florencia, Jáuregui (Discurso poético), fray Diego Niseno (Asuntos predicables)...

58. Para no resultar prolijo, podrán cotejarse en Roses Lozano (1994: 121-141) los criterios de los principales impugnadores y defensores de Góngora por lo que se refiere al decoro. Véase también Díaz de Rivas (1960: 51-53).

59. Véase Mazzocchi (2005). 
Quintero vuelve a exhibir su conservadurismo al juzgar desacertada la fusión de las cosas humildes con las voces grandes, y viceversa, de las tristes con las alegres, de las blandas con las duras, e così via; así como el trueque de las propiedades del epitalamio a la oración fúnebre, y al contrario. Tampoco falta su examen de la rota Vergilii, pasando revista al estilo de las Bucólicas y de la Eneida. Algo menos trillada, pero tampoco inédita en las preceptivas del Barroco, la pervivencia de cierto cratilismo platónico por lo que atañe al valor semántico y hasta metafórico de los fonemas (el salmantino llega a hablar ahora de letras «melancólicas» $\mathrm{y}$ «alegres»):

Y la valentía del hablar consiste en que la misma voz, sin atender a su significación sino a su sonido, exprima los conceptos del alma y ponga a los ojos lo que pretenden dar a conocer como el dolor de Títiro al ausentarse de su patria, diciendo a su ganado: «Ite meae quondam faelix pecus, ite capellae»; donde las M, F, P y LL van dando golpes en el sentimiento» (Quintero 1629: 32r).

Como digo, no abunda en las retóricas de la Edad de Oro, excepción hecha del Culto sevillano de su amigo Robles (1992: 215-254), que consagró el quinto diálogo de su obra a la ortografía, aunque el onubense pasa por alto este detalle del cratilismo, que sí hallamos, por ejemplo, en los Diálogos de Tasso, como ha sugerido Ponce Cárdenas (2010: 202) al examinar los versos más aliterativos del Polifemo: «en las doctinas poéticas de la época el fonema $M$ figura entre los "sublimes y magníficos" (Sebastián Fox Morcillo) y, en concreto, "conviene a los asuntos desmesurados y desagradables" (Vossius, con cita de Virgilio)»"

La distinción entre el poeta y el orador entrañaba una clara antinomia para Platón, Enio y Cicerón (Pro Archia Poeta), quienes juzgaban a los poetas «hijos de los dioses, padres de la sabiduría y sus versos inspiración y ardores del fuego incomprensible» (Quintero 1629: 33v). Luego el doctor evoca aquí la teoría del furor, desarrollada en el Renacimiento por López Pinciano en su Filosofía Antigua Poética (1596), según el cual la poesía disfrutaba de un origen divino. Roses (2008: 157-243) ha rastreado este binomio del ingenium y el furor desde el Manierismo (Carvallo) a Góngora, desembocando en la Apología en favor de don Luis de Góngora (1627), de Martínez de Portichuelo, para quien «los profetas y poetas no son ellos los que hablan (en cuanto poetas y profetas) cosas propias suyas, sino las deidades en ellos asistentes, que mediante la inspiración, como enfrenados a fuer de caballos los guían y llevan no por donde ellos quieren sino por donde y a donde ellas quieren" (Roses 2008: 218).

Insisto en que esa separación, cada vez más difusa en el Barroco por lo que concierne a sus públicos, viene de antiguo, documentándose en el marco de la

60. No obstante, Artaza (2015) explica en este mismo monográfico cómo Vives, en el libro III del De ratione dicendi, concedía ya importancia al sonido de las voces; $\mathrm{y}$ «si bien es cierto que el conducto de estas doctrinas es la Retórica de Trebisonda, hay que decir que las doctrinas mismas proceden del De compositione verborum de Dionisio de Halicarnaso. [...] No solo los autores citados dan una importancia capital al aspecto fónico de las palabras. Si nos adentramos en las retóricas barrocas, podría afirmarse lo mismo de otra interesante retórica valenciana del XVII, la de Francisco Novella, de 1641». 
polémica en el Libro de la erudición poética de Carrillo y Sotomayor (1992: 70): «No solo en los poetas es diferente el estilo, no solo en ellos se admitió el hablar en otra lengua, que en otra lengua afirma hablar el Príncipe de la elocuencia romana [Cicerón], aunque no por alabanza, sintiendo no haber alcanzado todas las alabanzas su lengua». Comparemos ahora la postura del baenense con esta de Quintero: «Por lo cual dijo Cicerón que los poetas parece que nos hablan en otra lengua» (Quintero 1629: 35r).

\section{DisCURSO SEGUNDO}

El segundo discurso del Templo (fols. 37r-53v), mucho más breve que el otro y hasta algo decepcionante, se encamina al uso de los predicadores y dibuja un boceto del estado en el que se encontraba la sermonística del primer tercio del Seiscientos. La idea subyacente es que también el púlpito admite ciertos arabescos, pero Quintero, siempre moderado, no se resiste a condenar la costumbre de dar gusto a los auditorios. Los únicos ejemplos de elocuencia permitidos al orador cristiano para que no se tuerza la «luz de la Escritura» son los de los Padres, que superan con largueza a los poetas gentiles, algunos de los cuales, según vimos, mencionó como responsables del desarrollo del castellano; por más que ahora, casi al final, parezca ignorar su apuesta por el «neologismo necesario», e incluso por Mena, Garcilaso y Góngora, para declarar que «la valentía de la Iglesia queda sin victorias [...] el día en que en sus pendencias y batallas del púlpito introdujéramos la lengua de oro, elocuente y perfilada de poetas y autores profanos» (Quintero 1629: 46v). Y se pregunta:

¿Qué gentil iguala la viveza en describir un huerto que tiene san Cipriano en la carta a Donato? ¿La valentía de sus razones, la majestad del lenguaje de San León Papa tan modestamente hinchado? ¿La dulzura de Ambrosio? ¿La fuerza culta de Jerónimo? ¿La viveza de Crisólogo? ¿Aquel raudal claro, fácil y docto en su fuente griega del divino Crisóstomo? ¿La concisión de Paulino? ¿Y el pensar levantado del africano Agustín? Todos elegantes con gravedad y dulces con valentía? (Quintero 1629: 38v)

Pero enseguida retrocede un par de pasos para dejar sitio a los autores profanos, siempre que se los nombre -argumento que linda con lo puerilcomo «el otro poeta» o «el gentil»:

y en estas asperezas no cierran del todo la puerta los santos a estas flores de lición y citas de filósofos, oradores y poetas; sino quieren que sean flores que no espesen el discurso ni embaracen los pastos de la Escritura que sustenta; que se traigan pocas veces al púlpito [...] al lascivo Propercio, al enamorado Ovidio y al ridículo Marcial, al mentiroso Apuleyo y al presumido Luciano (Quintero 1629: 48v).

Ignoro si existió algún contacto entre nuestro rétor y el granadino Pedro León y Moya, mínimo de la orden de San Francisco de Paula; quién leyó a quién o si manejaron la misma fuente intermedia. Lo cierto es que este párrafo del 
autor de los Aforismos y reglas para más bien ejercer el alto oficio de la predicación evangélica es idéntico al que acabo de reproducir:

Versos de poetas no se han de traer sino raras veces un versito y de cosa grave; que si no, advierte, será notar de loco al predicador. [...] No se han de citar poetas, a lo menos Ovidio, Marcial, Montemayor, Terencio, ni otros que trataron materias vanas. Bastará decir: allá vuestro poeta, o el otro en sus devaneos, aunque si suelen Virgilio, Homero y Horacio, se podrían nombrar con algún encogimiento» (León y Moya 1629: 17).

Como se sospechará, tampoco en esto fue original León, y menos aún Quintero, porque dos décadas antes Lorenzo de Zamora había dedicado la primera parte de su Monarquía mistica de la Iglesia hecha de hieroglificos sacados de humanas letras, en los sermones y comentarios de la Santa Escritura (Madrid, por Luis Sánchez, 1604) a debatir el problema de las citas de los poetas clásicos en los sermones y, en general, de la filosofía y la ciencia grecolatinas: «Lógicamente no aboga Zamora [...] por la entrada masiva e indiscriminada de poetas y filósofos paganos en el sermón; en un lugar pone como condición previa la selección de lo menos vulgar entre las obras de los gentiles» (García Berrio 1980: 212-214) ${ }^{61}$.

Entre los peores lastres de las conciones barrocas, Quintero incide en la ostentación de un lenguaje afectado que se sale de las esferas del orador para invadir las del poeta e incluso las del actor (Quintero 1629: 40r), saqueando para ello las Soledades indiscriminadamente:

Y no salga de la esfera de orador a las licencias afectadas de la curiosidad del poeta, sino que ciña el brazo con la ley de la prosa, y no le extienda, ni la hoz dé su elección a espigas que no son de su campo, alterando las voces y frasis ajenas, valiéndose para el lenguaje suelto de las bizarrías del poeta sin perdonar al lustro, precipicio, joven, deliquios y rosicleres, llamando archijardineras a las nubes, y sacando de las Soledades de Góngora versos enteros al sagrado del púlpito ${ }^{62}$.

Remiso a la mutación del templo en un teatro, prescinde del todo, pero asestándole un cintarazo, de la actio («aun con el rostro, al ademán o arqueo, no quiere que se lastimen los púlpitos a otros predicadores», Quintero 1629: 51v), de la moda de "predicar a los ojos" (Ledda 1989) y de las performances llenas de utilería (calaveras, crucifijos...) (Orozco Díaz 1980; Gentilli 2011) que eran capaces de desplegar los predicadores y misioneros de la España del XVII; al igual que de la inclusión de sátiras y desafíos ${ }^{63}$. Si hubiera que ceñirse

61. Sobre este asunto véase Herrero Salgado (1996: 292-294), quien valora las opiniones de fray Andrés de Valdecebro.

62. Con más finura de lo que sugiere Quintero es lo que había hecho, por ejemplo, Paravicino en su sermón de 1617 para las fiestas de Lerma, casi un centón, muy depurado, eso sí, de préstamos gongorinos del Polifemo y las Soledades, incluyendo escenas de caza de altanería. Véase Blanco (2012: 52-62).

63. Es una idea que se irá asentando en las retóricas eclesiásticas del XVII. Fuster (1681: 1-2), en su Brevisima método de componer sermones evangélicos que escribió a un amigo suyo, escribe que «tal vez se introduce, como que materia, alguna historia humana o dichos de filósofos o poetas, 
a su valoración de la poesía nueva, aun sin comulgar del todo con ella, «parece acercarse mucho más a los Discursos apologéticos de Pedro Díaz de Rivas o al Examen del antídoto de Francisco Fernández de Córdoba que a las censuras de Juan de Jáuregui o Francisco Cascales» (Tanganelli 2008: 314). Y diría que también tuvo en la uña el Libro de la erudición poética de Carrillo y Sotomayor, el Discurso poético del propio Jáuregui y quién sabe si el manuscrito del anónimo defensor de la Soledad I.

Hasta aquí mi larguísima homilía, que cierro con un acto de contricción. Soy consciente de la longitud y quiero creer que de la densidad teórica de estas páginas; igual que también sé que cualquier retórica, como nos ha recordado Azaustre Galiana (2013: 150), «se escribe para los oradores, no para los poetas, luego su aplicación al estilo de Góngora las está distanciando de su inicial propósito». Pero un rápido vistazo al Culto sevillano de Juan de Robles, que "concibió una retórica para un crítico en agraz, [...] una retórica para poetas» (Rico García 2015), al Templo de la elocuencia castellana y, más todavía, a su muy adelgazado discurso segundo, por no hablar del esfumato de la inventio, de la dispositio y de la actio en el primero, me faculta para clasificar esta obrita -un poco a lo Quevedo- como una proto-retórica; o mejor, como un retacillo de retórica, cuya cercanía al género hermano de la poética -ambas comparten la misma obsesión por el estilo- no impide fabular que el Templo también pudo servir para la instrucción de algún que otro bardo. Solo por eso, ha valido la pena, sin que sirva de precedente, juzgar los poemas de Góngora y los sermones de Paravicino, así como los de sus epígonos, cada vez más estilizados, más literaturizados si se quiere, del único modo que permite añadir el opúsculo de Quintero a la culta selva de textos que abonaron la polémica sobre las Soledades: retórica en mano.

\section{Bibliografía}

Álvarez Nogal, Carlos, Los banqueros de Felipe IV y los metales preciosos americanos (1621-1665), Madrid, Banco de España. Estudios de Historia Económica, 1997.

Ameyugo, Francisco, Retórica sagrada y evangélica ilustrada con la práctica de diversos artificios retóricos para proponer la palabra divina, Zaragoza, 1667.

Antonio, Nicolás, Bibliotheca Hispana Nova, Madrid, Ibarra, 1783, I.

Aragües Aldaz, José, Deus concionator. Mundo predicado y retórica del exemplum en los Siglos de Oro, Amsterdam - Atlanta, Rodopi, 1999.

Arellano, Ignacio, «Un misterio de Góngora aclarado: el animal tenebroso sale a la luz (Soledad I, 64-83), Criticón 120-121, 2014, 201-233.

Artaza, Elena, El ars narrandi en el siglo XVI espańol, Bilbao, Universidad de Deusto, 1989.

Artaza, Elena, «Las retóricas barrocas (1660-1650): notas introductorias», en Estudios de filología y retórica en homenaje a Luisa López Grigera, Elena Artaza et alii, eds., Bilbao, Universidad de Deusto, 2000, pp. 45-66.

mas ello ha de ser o para mayor declaración de la enseñanza o para ejemplo del suceso, con gravísima atención, no sea que tenga resabio alguno de inhonesto, de satírico o burlesco». 
Artaza, Elena, «De cambios estilísticos y paradigmas retóricos. Bizantinistas y antihermogenéticos», Bulletin Hispanique, n 1-2015, p. 11-24.

Azaustre Galiana, Antonio, «El uso retórico de las autoridades en las polémicas literarias sobre el estilo culto", en $A$ zaga de tu huella: homenaje al prof. Cristóbal Cuevas, coord. Salvador Montesa Peyró, 2005, I, pp. 309-334.

Azautre Galiana, Antonio, «Poesía y retórica en el Siglo de Oro: cuestiones en torno al estilo culto", en Los géneros poéticos del Siglo de Oro. Centros y periferias, ed. Rodrigo Cacho y Anne Holloway, London, Tamesis, 2013, pp. 133-150.

Baldissera, Andrea, «Poetas y poesía en el Jardín de la elocuencia de fray José Antonio de Hebrera (primera exploración)», Bulletin Hispanique, n 1-2015, p. 171-186.

Blanco, Mercedes, «Humanismo rezagado frente a difícil modernidad. Al margen de la polémica Ormaza-Céspedes sobre la oratoria sagrada», Criticón 84-85, 2002, 123 144.

Blanco, Mercedes, «Utpoesis, oratio. La oficina poética de la oratoria sacra en Hortensio Félix Paravicino", Lectura y signo 7.1, 2012, 29-65.

Blecua, Alberto, "Virgilio, Góngora y la nueva poesía», en La hidra barroca. Varia lección de Góngora, ed. Rafael Bonilla y Giuseppe Mazzocchi, Granada, Junta de Andalucía, 2008, pp. 119-127.

Bolzoni, Lina, La estancia de la memoria. Modelos literarios e iconográficos en la época de la imprenta, trad. de Giovanna Gabriele y Ma de las Nieves Muñiz, Madrid, Cátedra, 2007.

Bondía, Ambrosio de, Triunfo de la verdad sobre la Censura de la elocuencia, Madrid, Juan Martín de Barrio, 1649.

Bonilla Cerezo, Rafael, ed., Novelas cortas del siglo XVII, Madrid, Cátedra, 2010.

Bonilla Cerezo, Rafael, «Últimos azotes: el Arte de sermones de Martín de Velasco a la luz de la polémica Ormaza vs Céspedes», Lectura y signo, 7.1, 2012, 121-163.

Bonilla Cerezo, Rafael y Paolo Tanganelli, Soledades ilustradas. Retablo emblemático de Góngora, Salamanca, Delirio, 2013.

Carreira, Antonio, «Defecto y exceso en la interpretación de Góngora», en Gongoremas, Barcelona, Península, pp. 47-73.

Carrillo y Sotomayor, Luis, Libro de la erudición poética, ed. Angelina Costa, Sevilla, Alfar, 1992.

Cejador y Frauca, Julio, Historia de la lengua y literatura castellana (comprendidos los autores hispano-americanos). Desde los orígenes a Carlos V, Madrid, Gredos, 1972, IV-V.

Cerdan, Francis, Études sur Fray Hortensio Paravicino et la prédication de son temps, Presses Universitaires du Septentrion, 1994 .

Cerdan, Francis, ed., Fray Hortensio Paravicino, Sermones cortesanos, Madrid, Castalia, $1994 b$.

Cerdan, Francis, «Actualidad de los estudios sobre oratoria sagrada del Siglo de Oro (1985-2002). Balance y perspectivas», Criticón 84/85, 2002, 9-42.

Céspedes, Valentín de (alias Juan de la Encina), Trece por docena, ed. Francis Cerdan y José Enrique Laplana Gil, Anejos de Criticón, Presses Universitaires du Mirail, 1998. 
Daza Pinciano, Bernardino, Los emblemas de Alciato traducidos en rimas españolas, Lyon. Mathiam Bonhomme, 1549.

Díaz de Rivas, Pedro, Documentos gongorinos: los Discursos apologéticos de Pedro Díaz de Rivas; el Antídoto de Juan de Jáuregui, ed. Eunice Joiner Gates, México, Colegio de México, 1960.

Fumaroli, Marc, "Ut pictura rhetorica divina», en La scuola del silenzio. Il senso delle immagini nel XVII secolo, Milán, Adelphi, 1995, pp. 291-313.

Fumaroli, Marc, «Retórica, política y sociedad: del ciceronianismo al clasicismo francés", en La elocuencia en el Renacimiento. Estudios sobre la teoría y la práctica de la retórica renacentista, ed. James. J. Murphy, Madrid, Visor, 1999, pp. 301-324.

Fumaroli, Marc, L'Âge de l'eloquence, Genève, Droz, 2002.

Fuster, Melchor, Brevisima método de componer sermones evangélicos que escribió a un amigo suyo, Valencia, Francisco Mestre, 1681.

Galbarro, Jaime, «Hacia una catalogación de las retóricas españolas más importantes del siglo XVII. Modelos, tendencias y canon poético", en El canon poético en el siglo XVII, ed. Begoña López Bueno, dir., Sevilla, Grupo PASO, 2010, pp. 73-92.

García Berrio, Antonio, Formación de la teoría literaria moderna / 2. Teoría poética del Siglo de Oro, Murcia, Universidad, 1980.

García Berrio, Antonio y Teresa Hernández Fernández, Ut poesis pictura. Poética del arte visual, Madrid, Tecnos, 1988.

García Martínez, Antonio Claret, La escritura transformada. Oralidad y cultura escrita en la predicación de los siglos XV al XVII, Huelva, Universidad, 2006.

García Matamoros, Alfonso, De tribus dicendi generibus sive de recta informandi styli ratione commentarius cui accessit de Methodo concionandi, Alcalá, taller de A. Angulo, 1570.

Gentilli, Luciana, «En la escena del mundo: la performance de predicadores y misioneros en la España del siglo XVII», en Emocionar escribiendo. Teatralidad y géneros literarios en la España áurea, ed. Luciana Gentilli y Renata Londero, Madrid / Frankfurt am Main, Iberoamericana / Vervuert, 2011, pp. 197-215.

Gerli, Michael, «El castillo interior y el arte de la memoria», Bulletin Hispanique, 86.12, 1984, pp. 154-163.

Gómez Camacho, Alejandro, «Introducción» a Juan de Robles, El culto sevillano, ed. Alejandro Gómez Camacho, Sevilla, Universidad, 1992, pp. 11-31.

Góngora, Luis, Soledades, ed. Robert Jammes, Madrid, Castalia, 1994.

Góngora, Luis de, Romances, ed. Antonio Carreira, Barcelona, Quaderns Crema, 1998, 4 vols.

Góngora, Luis, Obras completas, ed. Antonio Carreira, Madrid, Biblioteca Castro, 2000, 2 vols.

Góngora, Luis de, Fábula de Polifemo y Galatea, ed. Jesús Ponce Cárdenas, Madrid, Cátedra, 2010.

González García, Juan Luis, “¿"Vencen al arte del decir”? Estilo, decoro y juicio crítico de los pintores-predicadores de los siglos XVI y XVII», en Sacar de la sombra luz. La teoría de la pintura en el Siglo de Oro (1650-1724), ed. José Riello, Madrid, Abada Editores / Museo Nacional del Prado, 2012, pp. 87-104.

Gunderson, Erik, "The Rhetoric of Rhetorical Theory», en Ancient Rhetoric, ed. Erik Gunderson, Cambridge, University Press, 2009, pp. 109-125. 
Hebrera y Esmir, José Antonio, Jardín de la elocuencia oratoria, poética y politica, Zaragoza, 1677.

Hermenegildo Dávila, Manuel, Salustiano Ruiz y Santiago Diego Madrazo, Reseña histórica de la Universidad de Salamanca, Salamanca, Imprenta de Juan José Morán, 1849.

Herrero García, Miguel, Sermonario clásico: con un ensayo sobre la oratoria sagrada, Madrid, Escélicer, 1942.

Herrero Salgado, Félix, La oratoria sagrada en los siglos XVI y XVII, Madrid, FUE, 1996. Herrero Salgado, Félix, «Las citas en los sermones del Siglo de Oro», Criticón 84/85 (2002) 63-79.

Herrero Salgado, Félix, La oratoria sagrada en los siglos XVI y XVII. Predicadores de la orden de la Santísima Trinidad. Predicadores mercedarios. Predicadores procesados por la Inquisición, Madrid, FUE, 2006, tomo V.

Jammes, Robert, «Comentarios y apéndices» a Luis de Góngora, Soledades, ed. Robert Jammes, Madrid, Castalia, 1994, pp. 181-716.

Jammes, Robert, «Apéndice II: La polémica de las Soledades (1613-1666)» a Luis de Góngora, Soledades, ed. Robert Jammes, Madrid, Castalia, 1994, pp. 605-719.

Jáuregui, Juan de, Discurso poético, ed. Melchora Romanos, Madrid, Editora Nacional, 1978.

Jáuregui, Juan de, Antídoto contra la pestilente poesía de las Soledades, ed. José Manuel Rico García, Sevilla, Universidad, 2002.

Jungemann, Frederick H., La teoría del sustrato y los dialectos hispano-romances y gascones, Madrid, Gredos, 1956.

Lázaro Carreter, Fernando, «Imitación compuesta y diseño retórico en la Oda a Juan de Grial”, Anuario de Estudios Filológicos 2, 1989, 89-119.

Ledda, Giuseppina, «Predicar a los ojos», Edad de Oro VIII, 1989, 129-142.

Lee, Rensselaer W., "Ut Pictura Poesis: The Humanistic Theory of Painting», The Art Bulletin XXII, 1940, 196-269.

León y Moya, Pedro, Aforismos y reglas para más bien ejercer el alto oficio de la predicación evangélica según doctrina de santos y escritores antiguos y modernos, Antequera, Manuel Botello de Payva, 1629.

Lichtenstein, Jacqueline, La couleur éloquente. Rhétorique et peinture à l'Âge Classique, Paris, Flammarion, 1989.

Lleó Cañal, Vicente, Nueva Roma: mitología y humanismo en el Renacimiento sevillano, Sevilla, Diputación Provincial, 1979.

Lleó Cañal, Vicente, «Minerva Bética. Sobre literatura y pintura», en La «idea» de la poesía sevillana en el Siglo de Oro, dir. Begoña López Bueno, Sevilla, Universidad, 2012, pp. 73-91.

López Grigera, Luisa, La retórica en la España del Siglo de Oro, Salamanca, Universidad, 1994.

López Poza, Sagrario, «La cultura emblemática bajo el valimiento del duque de Lerma (1598-1618)", en El duque de Lerma. Poder y literatura en el Siglo de Oro, dirs. Juan Matas, José María Micó y Jesús Ponce, Madrid, CEEH, 2011, pp. 235-262.

Luján Atienza, Ángel L., "La retórica hallada de Mateo Bossulo», Revista de Literatura LX.119, 1998, 31-43. 
Luján Atienza, Ángel L., «Ramismo y Ciceronianismo en los tratados de retórica de la Universidad de Valencia en el siglo XVI», en Grau Codina, Gómez Font, Pérez Durà, Estellés González (eds.), La Universitat de València y l'Humanisme: 'Studia Humanitatis' i renovació cultural a Europa i al Nou Món, Valencia, Universitat de València, 2003, pp. 297-302.

Luján Atienza, Ángel L. "Juan Lorenzo Palmireno y el canon estilístico de la literatura vernácula», Bulletin Hispanique, no 1-2015, p. 43-64.

Martí, Antonio, La preceptiva retórica en el Siglo de Oro, Madrid, Gredos, 1972.

Mazzocchi, Giuseppe. «La estructura narrativa del Polifemo», en El Polifemo de Góngora, ed. Joaquín Roses, Córdoba, Diputación, 2005, pp. 125-138.

Meerhoff, Kees, Rhétorique et Poétique au XVI siècle en France. Du Bellay, Ramus et les autres, Leiden, Brill, 1986.

Menéndez Pelayo, Marcelino, «Prólogo» a Pedro de Quirós, Poesías divinas y humanas, Sevilla, El Orden, 1887.

Mohrmann, Gerald P., «La elocutio y otros problemas de la crítica actual sobre la retórica del Renacimiento inglés», en La elocuencia en el Renacimiento. Estudios sobre la teoría y la práctica de la retórica renacentista, ed. James. J. Murphy, Madrid, Visor, 1999, pp. 76-107.

Muñoz, Luis, Vida y virtudes del V. P. M. Fr. Luis de Granada, del Sagrado Orden de Predicadores, Madrid, Oficina de Manuel Fernández, 1780, IX.

Núnez Beltrán, Miguel Ángel, La oratoria sagrada de la época del barroco. Doctrina, cultura y actitud ante la vida desde los sermones sevillanos del siglo XVII, Sevilla, Universidad de Sevilla, Fundación Focus Abengoa, 2000.

Ong, Walter Jackson, Ramus, Method, and the Decay of Dialogue, Cambridge (Mass.), Harvard University Press, 1958.

Orozco Díaz, Emilio, «Sobre la teatralización del templo y la función religiosa en el Barroco: el predicador y el comediante», Cuadernos para Investigación de la Literatura Hispánica 2-3, 1980, pp. 171-188.

Osuna Cabezas, María José, Góngora vindicado: Soledad primera, ilustrada y defendida, Zaragoza, Prensas Universitarias, 2009.

Osuna Cabezas, María José, Las Soledades caminan hacia la corte. Primera fase de la polémica gongorina, Vigo, Academia del Hispanismo, 2009.

Palmireno, Lorenzo, La segunda parte del latino de repente, Valencia, Pedro Huete, 1573. Pascual Barea, Joaquín, "La Epistola Commendatitia de Jacinto Carlos Quintero para la proyección edición en Flandes de los Veteris Hispaniae Dei de Rodrigo Caro", en Supplementa Humanistica Lovaniensia XXVI. Syntagmatia. Essays on Neo-Latin Literature in Honour of Monique Mund-Dopchie and Gilbert Tournoy, ed. Drik Sacré y Jan Papy, Leuven, Leuven University Press, 2009, pp. 623-638.

Pérez de Ledesma, Gonzalo, Censura de la elocuencia (Zaragoza, 1648), introd. Giuseppina Ledda y texto de Giuseppina Ledda y Vittoria Stagno, Madrid, Anejos de El Crotalón, 1985.

Pérez Lasheras, Antonio, "Góngora y los clásicos», en La hidra barroca. Varia lección de Góngora, ed. Rafael Bonilla y Giuseppe Mazzocchi, Granada, Junta de Andalucía, 2008, pp. 129-141. 
Pérez López, Manuel María, Pedro de Valencia, primer crítico gongorino: estudio y edición anotada de la carta a Góngora en censura de sus poesías, Salamanca, Universidad, 1988.

Piñero, Félix, «La tradición apócrifa del pasaje del carbunclo (Góngora, Soledad I, 74)», en Isabel Colón y Jesús Ponce, eds., en Estudios sobre tradición clásica y mitología en el Siglo de Oro, Madrid, Ediciones Clásicas, 2002, pp. 27-35.

Plett, Heinrich F., "Lugar y función del estilo en la poética renacentista», en La elocuencia en el Renacimiento. Estudios sobre la teoría y la práctica de la retórica renacentista, ed. James. J. Murphy, Madrid, Visor, 1999, pp. 421-443.

Ponce Cárdenas, Jesús, «El enigma de la fiera: sobre la zamarra del cíclope», en Cinco ensayos polifémicos, Málaga, Universidad, pp. 171-239.

Portús, Javier, «Tratados de pintura y tratados de imágenes sagradas en la España del Siglo de Oro", en Sacar de la sombra luz. La teoría de la pintura en el Siglo de Oro (1650-1724), ed. José Riello, Madrid, Abada Editores / Museo Nacional del Prado, 2012, pp. 21-31.

Quintero, Benito Carlos, Templo de la elocuencia castellana, Salamanca, Rodrigo Calvo, 1629.

Quintero, Benito Carlos, Templo de la elocuencia castellana, Sevilla, Luis Estupiñán, 1629.

Rico García, José Manuel, «La poesía en El culto sevillano de Juan de Robles: la evocación del sueño del Humanismo en Sevilla», Bulletin Hispanique, n 1-2015, p. 143-158.

Rico Verdú, José, La retórica española de los siglos XVI y XVII, Madrid, CSIC, 1973.

Robles, Juan de, El culto sevillano, ed. Alejandro Gómez Camacho, Sevilla, Universidad, 1992.

Rodríguez de la Flor, Fernando, Teatro de la memoria: siete ensayos sobre mnemoctenia española de los siglos XVII y XVIII, Junta de Castilla y León, 1988.

Rodríguez de la Flor, Fernando, «La península metafísica. Crisis de las letras y decadencia general del saber en la Espańa del Antiguo Régimen», en La península metafísica. Arte literatura y pensamiento en la España de la Contrarreforma, Madrid, Biblioteca Nueva, 1999, pp. 19-58.

Rodríguez de la Flor, Fernando, «El poder de los emblemas. El espacio políticofigurativo de la emblemática cortesana», en Mundo simbólico. Poética, politica y teúrgia en el Barroco hispano, Madrid, Akal, 2012, pp. 103-136.

Roses Lozano, Joaquín, Una poética de la oscuridad. La recepción critica de las Soledades en el siglo XVII, Madrid-London, Tamesis, 1994.

Roses, Joaquín, «Medio siglo de crítica literaria en torno a las Soledades», en Una densa polimorfía de belleza. Góngora y el grupo del 27, ed. Andrés Soria Olmedo, Sevilla, Junta de Andalucía, 2007, pp. 81-119.

Roses, Joaquín, Soledades habitadas. Retablo emblemático de Góngora, Málaga, Universidad, 2008.

Ruiz Pérez, Pedro, «Juan de Arguijo y la literatura barroca oral», en El Barroco en Andalucía, ed. Manuel Peláez del Rosal, Córdoba, Universidad, 1984, II, pp. 33-41.

Ruscelli, Girolamo, Le imprese illustri, Venezia, Francesco de Franceschi, 1584.

Salazar y Castro, Luis de, Jornadas de los coches de Madrid o satisfacción al Palacio de Momo a las apuntaciones a la Carta del Maestro de Niños, Zaragoza, 1714. 
Salcedo de Aguirre, Gaspar, Pliego de Cartas en que ay doze epistolas escritas a personas de diferentes estados y officios..., Baeça, por Iuan Baptista de Montoya, 1594.

Samonà, Carmelo, «Poesia, teatro: un incontro di forme. L'esperienza cultista nell'età di Lope» (1964), en Ippogrifo violento. Studi su Calderón, Lope e Tirso, Milano, Garzanti Editore, 1990, pp. 109-187.

Sebold, Russell P., "Mena y Garcilaso, nuestros amos”: Solís y Candamo, líricos neoclásicos», en La perduración de la modalidad neoclásica. Poesía y prosa españolas de los siglos XVII al XIX, Salamanca, Universidad de Salamanca, 2001, pp. 39-55.

Sieber, Harry, "Clientelismo y mecenazgo: hacia una historia cultural literaria de la corte de Felipe III", en Actas del IV Congreso Internacional de la AISO (Alcalá de Henares, 22-27 de julio de 1996), ed. María Cruz García de Enterría y Alicia Cordón Mesa, Alcalá de Henares, Universidad, 1998, pp. 95-112.

Smith, Hillary Dansey, Preaching in the Spanish Golden Age, Oxford, University Press, 1978.

Soria Ortega, Andrés, El Maestro Fray Manuel de Guerra y Ribera y la oratoria sagrada de su tiempo, estudio preliminar de Francis Cerdan, Granada, Universidad de Granada, 1991.

Tanganelli, Paolo, «En torno a las interpolaciones del Cántico B: algunas peculiaridades léxicas y una nueva técnica descriptiva», San Juan de la Cruz XXIV.42, 2008, 57 106.

Tanganelli, Paolo, «La crisis de la oratoria sagrada entre los siglos XVII y XVIII: el Epitome de la elocuencia española de Artiga y los modelos descriptivos de la predicación gerundiana», Annali Online di Ferrara-Lettere 1, 2008, 124-138.

Tanganelli, Paolo, Le macchine della descrizione. Retorica e predicazione nel Barocco spagnolo, Como, Ibis, 2011.

Tanganelli, Paolo, «En la gloria en donde el lenguaje es ver»: Algunas notas sobre las técnicas de visualización en el sermón barroco", Lectura y signo 7.1 (2012) 217-220.

Vargas Lugo, Elisa, «Los predicadores mudos», en Los discursos sobre el arte. XV Coloquio Internacional de Historia del Arte, México, Universidad Nacional Autónoma de México, 1995, pp. 55-68.

Velasco, Martín de, Arte de sermones para saber hacerlos y predicarlos, Cádiz, Bartolomé Núñez de Castro, c. 1675.

Vidal y Díaz, Alejandro, Memoria histórica de la Universidad de Salamanca, redactada en virtud del encargo del señor don Vicente Lobo, rector de la misma... fecha 6 de abril de 1869, ed. facsímil, Valladolid, Editorial Maxtor, 2007.

Waley, Pamela, "Some Uses of Classical Mythology in the Soledades de Góngora», Bulletin of Hispanic Studies, XXXVI, 1959, 193-209.

Ward, John O., "Los comentaristas de la retórica ciceroniana en el Renacimiento», en La elocuencia en el Renacimiento. Estudios sobre la teoría y la práctica de la retórica renacentista, ed. James. J. Murphy, Madrid, Visor, 1999, pp. 157-210.

Zamora, Lorenzo de, Monarquía mistica de la Iglesia hecha de hieroglificos sacados de humanas letras, en los sermones y comentarios de la Santa Escritura, Madrid, Luis Sánchez, 1604. 
